\title{
The role of pension funds in the financialisation of the Icelandic economy
}

Capital \& Class

36(3) 433-473

(c) The Author(s) 2012

Reprints and permission: sagepub. co.uk/journalsPermissions.nav DOI: $10.1177 / 0309816812460753$

c\&c.sagepub.com

\section{Francesco Macheda}

Università Politecnica delle Marche, Italy

\begin{abstract}
This article explores the decisive role of pension funds in the neoliberal restructuring of the lcelandic economy, arguing that, through their involvement in the pensionfund industry, the labour unions contributed to laying the foundations for Iceland's economic financialisation. The socioeconomic stability provided by the labour organisations was the crucial element upon which the new financial regime of accumulation relied, enhancing the national economic 'credibility' that helped the internal market to attract foreign speculators as well as gaining access to loans from international market. I begin by examining how the structural crisis of the Icelandic economy produced an explosion of inflation and industrial conflict in the late-1980s. I then retrace the way the implementation of a neo-corporatist pattern enabled lower inflation and stabilisation of the currency. Finally, I analyse the way in which the involvement of the Icelandic trade unions in the financial mechanisms through the pension industry generated a degree of identification with pro-market governmental policy on the part of union leaders, encouraging them to tailor their own strategies accordingly. My conclusion is that Icelandic unions' consensus concerning the 'stabilisation programme' implemented by the neoliberal coalitions relies on their embeddedness into the financial structures of the national economy through occupational pension funds.
\end{abstract}

\section{Keywords}

Pension funds, financial expropriation, industrial relations, trade unions, political economy

\section{Introduction}

This article attempts to address the gap in the existing literature regarding the process of development in the institutions making Icelandic financialisation socially and politically

\section{Corresponding author:}

Francesco Macheda, Università Politecnica delle Marche, Italy

Email: f.macheda@univpm.it 
possible. By focusing on the development of the occupational pension funds, my goal is to retrace the macro-social and political foundations of the strategies and behaviours of economic actors during the building process of the financial architecture in Iceland since the early 1990s. In particular, this paper attempts to mount a challenge to conventional perspectives on the role labour organisations are normally conceived to play in the generation of national economic policy.

In a small market context such as Iceland's, occupational pension funds are one of the most important players in the country's financial markets (Jónsson, 1999: 32-35), closely integrated into private banking, the investment system, and industrial relations. Pension fund assets experienced an apparently endless growth, reaching an astonishing share of 133 per cent of GDP at the end of 2007. They increased by more than twenty times in real terms from 1980 - the second highest increase among OECD countries, after the Netherlands. At the same time, workers retirement savings soared to 31 per cent of total domestic saving in 1997 (even higher than the bank savings share), providing a fundamental source of liquidity that underpinned the financial industry. The enormous importance of pension funds in the national economy makes trade union leaders, who control them in cooperation with the employers and 'pension funds money managers', very influential in the economic and political life of the country. As Ásmundur Stefánsson, the president of the Icelandic Federation of Labour (ASÍ) from 1980 to 1992, proudly declared, 'ASÍ has broken away from political conflict and is now a leading force in the country, not the political parties. It is rather the political parties that seek assistance from ASÍ ... It is no question that we have managed to regulate many things in the last years' (Baldvinsdóttir, 1998: 158).

Iceland's peculiar development, therefore, makes it especially useful as a case study for analysing how markets do not automatically produce 'the various prerequisites that are necessary for their implementation' (Hollingsworth and Boyer, 1997: 434); or, to put the matter in another way, how the impressive expansion of financial activity was sustained by powerful extra-market forces. In general, this expansion has often been referred to as 'financialisation', and identifies the building process of the 'pattern of accumulation in which profit making occurs increasingly through financial channels rather than through trade and commodity production' (Krippner, 2004: 14). The range of phenomena that gives concrete life to the concept of financialisation - from the deregulation of the financial sector to the rise of speculative investment associated with the re-emergence of the rentier - has shaped the pattern of accumulation in many capitalistic economies in the last twenty to thirty years. Although the extent to which these phenomena prevailed in one country as opposed to another has been quite uneven, there are five striking traits that characterise the new finance-led regime of accumulation:

1) The deregulation of financial markets, new technologies and financial innovations leading to an increase of capital flows.

2) Increased profits of both financial and non-financial corporations that do not promote increased productive investment.

3) The ideological ascendancy of 'shareholder value' in guiding corporate governance.

4) Consumption expenditures become the driving force for growth as households gain improved access to credit. 
5) The penetration of finance into what we might call social and economic workers' reproduction (Stockhammer, 2008; Fine, 2009).

The most influential theoretical perspectives that tackle the question of financialisation - from Marxism to post-Keynesians - legitimately focus on the first four points, i.e. the economic side. On one hand, by analysing its causes, they rightly trace the expansion of the financial sphere back to the stagnation of production in the mid-1970s. On the other, many scholars put considerable effort into describing the effects of the growth of finance, mainly focusing on poor economic performance compared to the previous period, the increasing instability of financialised economies, and so on. Without a doubt, these questions are at the heart of the matter, and are worthy of deep investigation. Yet by excluding the penetration of finance into social and economic workers' reproduction, in which labour organisations are still heavily involved, the relationship between the two fundamental classes within capitalism is forced into the background, which ignore[s] the impact of the envisioning institutions of power with which trade unions constantly interact' (Hyman, 1975: 69). At worst, the working class's withdrawal is seen in terms of trade union bureaucracy's betrayal of member's interests, materialised by unions leaders' accommodating union behaviour to employers' prerogatives. At best, labour organisations are simply considered as passive subjects, substantially weakened in their traditional form, by changes in the political sphere and the response to neoliberalism of the socialdemocratic parties to which unions were historically linked (McIlroy and Daniels, 2009: 7). The result is that, since social relations between classes are thrown out of the analysis, the institutional building process that supports financialisation is often interpreted either in terms of an agency problem or, at the other extreme, as an objective and impersonal path. In both cases, the fact that social relations determine institutions is overlooked because the former are the conditions of existence of the latter, in the sense that social relations transfer their contradictory social content to institutions (Carchedi, 2001: 7).

To focus on the infiltration of finance in social and economic workers' reproduction might prove useful in order to throw light on the socio-political prerequisites underlying the new paradigm of accumulation centered on finance. Put another way, the goal is to reintegrate the class analysis in the academic discourse regarding the phenomena of financialisation. Two factors explain the decision to inquire into the financialisation of workers' income. First, although taking different forms compared to past phases, the fuel that directly and indirectly drives capitalism in all its forms still flows from the very relationship between labour and capital, i.e. surplus value. As mentioned above, financialisation represents a profound shift away from direct investment in productive capacity, towards the open financial markets in which profitability can be temporarily boosted through speculative operations in the stock markets (Lucarelli, 2011: 113-115). In this process, the transformation of the future streams of income into marketable and traded assets in the form of equities or bonds (Vasudevan, 2009: 30) through privatisation of social provisions is strongly interrelated to the ascendancy of a finance-led regime of accumulation. In fact, the parallel process of public welfare retreat has meant that workers and their families have come to rely on the market for social provision such as pensions. In this way, they have been increasingly forced into the arms of the financial system, triggering massive flows of lendable money capital. Nevertheless, the incorporation 
of financial markets into the process of welfare provision meant a shift away from the common strategy of exploiting labour into the production sphere, towards the shortterm strategy of extracting profit directly out of wages and salaries into the sphere of circulation. This movement of purchasing power between actors in the economy is what Lapavitsas named 'financial expropriation', because savings across society are pooled and transformed into loanable money capital from which interest can be earned. Thus financial markets expropriate workers' savings. However, within the new financial domain, enterprise and workers are motivated by different goals. The former focuses on the expansion of exchange value (profits) by appropriating loanable money capital originating in wages. The latter, instead, focuses on obtaining use-values like pensions, seeking to secure their future consumption for tomorrow's retirement (Lapavitsas, 2009).

Second, although it is undeniable that the disciplinary force of the financial markets is often at odds with labour wages as well as welfare state expansion, in many countries the trade unions constituted a fundamental actor in the definition and in the implementation of the macro and micro-policies underpinning the process of economic financialisation. While in some countries like the UK and the USA, the deflation road included a frontal attack on labour organisations, in some others, like Iceland, the Netherlands, Sweden or Ireland, it can safely be stated that trade unions became increasingly ready to collaborate in the definition and the implementation of some macroeconomic policies, such as the privatisation of the social risk (Trampusch, 2006; Belfrage and Ryner, 2009; Baccaro and Howell, 2011: 545-547). In this framework, one of the crucial extra-market institutions that matters most in the social construction of financial markets is the occupational pension fund, which appears as a key component in forging a broader class alliance in favor of neoliberal restructuring (Duménil and Lévy, 2004: 129). By redefining the power relationships in the national arena and within the firms, pension funds, on the one hand, constitute a central mediating mechanism between the financial markets of transnationally mobile capital, core reproductive functions of the welfare state, and everyday saving and consumption over the life cycle (Belfrage and Ryner, 2009: 258). On the other hand, they are a decisive device that interlinks the unions', employers' and government's actions, embedding industrial relations in a financial economic context within domestic boundaries. These complex networks have generated a structure of social relations in which even trade unions, acting in what they perceive to be their own interests, can produce effects that may be quite different, perhaps even diametrically opposed, to what they intended (Cowan, 1987: 279). As the analysis of the Icelandic case reveals, this is the crux of the matter: labour union leaders find themselves on both sides of the negotiating table, since it is often the same people involved in collective bargaining who are also managing pension funds for workers in cooperation with the employers. On one hand, as workers' representatives they are supposed to bargain for expansive 'pro-labour' policies, to their membership's advantage. On the other, as members of a financial institution (pension fund), they became strongly connected to influential members of employers and financial communities in sustaining neoliberal measures to boost pension assets, to shareholders' advantage.

The financialisation of the social and economic reproduction of the working class through the occupational pension industry has therefore, in this sense, come down to disputes over economic policy issues in which the different interests of labour and capital are at stake. As Keynes (2000) pointed out, within an industrial society, business and 
labour tended to favour an expansionary and potentially inflationary alternative, in opposition to the financial interests that preferred a deflationary policy. By becoming integrated into the decision-making process of a financial institution, whose wealth is denominated in terms of money, the social compromise between labour and capital is redefined, having both material and objective reasons to strongly oppose inflation, and in the meantime, to agree with the opening of the market in order to find more profitable opportunities in which to invest. Arguably, the worker organisations involved in occupational pension funds management should not be considered as merely passive players during the phase of economic financialisation, but rather as fundamental players helping to secure a certain stability and predictability in [financial] accumulation despite the fundamental contradictions and conflicts generated by the very dynamic of capitalism (Jessop, 2006: 4).

The redefinition of capital-labour-power relations and their recent fusion with financial institutions, as discussed above, suggest that conventional theoretical approaches to industrial relations suffer from certain explanatory limitations. Under industrial capitalism, power, for the capitalist class, is identical with capital's command over labour both in workplaces and in the labour market. In the first place, capitalists and their agents have control over the process of production, and use their dominant position in capitalist society to compel workers to expend an extended period of effort at the workplace beyond what is required to make back their wages, which forms the basis for capitalist profit (Shaikh, 1986: 167). In the labour market, the complex and concrete (and shifting) categories incorporating the full range of socioeconomic relations, structures and tendencies (Fine, 2007: 128), mainly among employers, unions and the state, have tended to produce conditions that reinforce the stability of the exploitive capital-labour relation. The analysis of the process of control over work relations, i.e. the exploitation of surplus value in the sphere of production and its social preconditions and reflection in the labour market, has constituted the normal object of study in the industrial relations of industrial societies (Hyman, 1975).

To be clear, although the relationship between capital and labour has achieved greater obfuscation due to financialisation, industrial relations are no less crucial in regulating interrelations binding the two major classes in contemporary capitalism. As part and parcel of the historical forms of capitalism, industrial relations transform as new generalised structural imperatives emerge historically, which in the current period have centred around the search for profits in the sphere of circulation. The co-evolution of industrial relations with the financial institutions causes more or less radical institutional changes - depending on the extent of the changes in the pattern of alliances between social blocks and political actors (Amable et al., 2005: 372) - which, in turn, redefine the institutional complementarities among financial regulations, industrial relations, and political economic institutions. To grasp more completely the changed parameters structuring interaction between social actors, a deep aggiornamento in the study of the industrial relation is required. Financialisation has actually undermined the boundaries previously separating financial institutions, so that labour laws, collective bargaining and individual labour contracts are now shaped in significant ways by factors which used to be largely outside their conventional domain of investigation (Boyer, 1996: 21).

First, it is fundamental to determine how the transformation, due to the internationalisation of the financial market, has shifted the balance of power of various groups and 
economic specialisations via the re-deployment of the strategies of the firms, the banks, the unions, the government and the state (Boyer, 1996: 5). Second, it is equally essential to highlight the level of embeddedness and/or the control of the industrial relations institutions of financial structures of the national economy.

Despite the importance of pension funds in relation to the size of Iceland's economy, and the primary role of the national trade unions, to this date these theoretical and empirical insights have not been fully applied to analyse the social forces at the root of one of the most destructive examples of liberal capitalism: the Icelandic case. Many of the articles that have tried to inquire into the rise of Icelandic imbalances merely provide subjective or contingent explanations of the very causes behind the failure of Iceland's financial system, such as the supposedly weak business culture of Icelandic society (Vaiman et al., 2011), the risky expansion strategies pursued by the banks (Carey, 2009), or the implementation of the neoliberal agenda by a new generation of young politicians that came to power in the 1990s (Benediktsdóttir et al., 2011). In a more complex version, the Icelandic crisis is the outcome of the interaction between policy and management errors, like the fiscal policy of the government, the monetary policy of the Central Bank of Iceland, and the financial supervision, corporate governance and risk management of the banks (Sigurjónsson and Mixa, 2011).

Unfortunately, the heterodox literature also seems to neglect Polanyian and Regulationist intuitions, causing it to fall into the trap of financial determinism. In their recent article, 'Iceland's meltdown: The rise and fall of international banking in the North Atlantic', Robert Wade and Silla Sigurgeirsdóttir (2011), although providing a very convincing historical reconstruction of the fall of the Icelandic banking system, fail to keep the other promise in the article's title, i.e. the explanation of the rise of the banking systems in Iceland. The reason is threefold. First, because of their adoption of a shortperiod perspective, the authors neglect the structural conditions that are at the base of the reallocation of investments from production to speculative activities. In order to inquire into the upsurge of the Icelandic 'international banking', Wade and Sigurgeirsdóttir limit themselves to exogenous factors, i.e. the Fed's flood of liquidity on international markets, coupled with the ongoing process of the privatisation of the Icelandic banking system. The question of whether it is true that such interaction made foreign borrowing by Icelandic banks easier does not explain either the reason why Iceland privatised its banking system only at the dawn of the third millennium, nor what has pushed both the political and economic powers of Iceland to abandon their traditional support for the fishing sector in favor of the financial sector. Secondly, by laying the blame for the liberal turn in Iceland from the mid-1990s only on a greedy 'shadow elite', the authors exclude from their visual field another actor of no less importance, which provided the socioeconomic stability necessary to enhance the national economic 'credibility' in order to attract foreign speculators in the internal market, and to gain access to loans by international markets (Screpanti, 2001); namely, the trade unions. Through their involvement in neocorporative pacts in the early 1990s, the workers' organisations changed from being causes of 'disorder' into resources for political and social order, instrumental in lowering inflation and currency stabilisation. This in turn made an opening in the capital market possible, thus creating the necessary structural conditions for financial capital to erupt at the end of the decade. However, as a particular medium of regulating social relations, the monetarist criteria reinforced the risk that the trade unions' strategies were subordinated 
to purely monetary consideration. Wade and Sigurgeirsdóttir simply rule out the function of the trade unions and their relationship with employers and the state in laying the material basis for the creation of the financial institutions that boosted the economy from the late-1990s. For them, the neoliberal wave that struck Iceland is solely attributable to a 'dozen or so men studying law or business administration at the University of Iceland' during the 1970s, who refashioned society under a neoliberal model when they moved into positions of power (Wade and Sigurgeirsdóttir, 2011: 59). The trouble with this approach, i.e. of relying exclusively on human behaviour, is that it does not substantially depart from orthodoxy, where the economic crisis is explained in terms of human mistakes originating in inadequate regulative frameworks.

The under-theorisation of both the connection between the crisis of the primary sectors and the development of the banking sector, as well as the key role of trade unions in guaranteeing the social stability that was indispensable to the implementation of the monetary regime, leads to the third reason behind the breaking of the promise made by Wade and Sigurgeirsdóttir. Being blind to these issues, in fact, does not excuse them from not taking into account the key institution that constitutes a central mediating mechanism between industrial restructuring and labour's 'forced consensus' for the economic liberalisation and growth of the financial markets; namely, the occupational pension funds. In the first place, the pension funds' administration tasks cast doubt on the hypothesis of a univocal shadow elite's responsibility regarding the neoliberal turn. Indeed, the pension fund system, prior to the emergence of strong financial markets, served an indirect pedagogical function by training investment managers and providing challenging opportunities for young experts often educated abroad at major business schools. The opportunity to manage pension funds' assets as well as the constant need for new financial products provided opportunities for a new generation of financial managers (Herbertsson, 2005; Portes et al., 2007). But what is more important is the fact that, as one of the largest savings institutions in the country, these funds not only benefited from the set of monetarist measures mentioned above, but also stimulated strong demand for new channels of speculative investment, 'contributing significantly to the development of financial markets in Iceland' (Guðmundsson, 2001: 2-20). During the latter half of the 1990s, the funds became more active on the domestic equity market as that market developed, and the funds were 'increasingly looking for alternative investment opportunities to the domestic bond market' (Guðmundsson, 2001).

The preference for equities amongst pension funds in Iceland - which has contributed significantly to the growth of stock markets in the country (OECD, 2008: 65) - has deep historical and institutional roots. To begin with, the Icelandic pension system is one of the more privately oriented among the Nordic countries, and is closer in nature to the pension systems in the UK and USA (Ólafsson, 1999). In the Icelandic model, payments under public pay-as-you-go (PAYGO) regimes grounded in social citizenship rights and financed directly out of taxes are quite low by international standards. ${ }^{1}$ Over the last twenty years, the income testing of pensions has been increased and the development of public pension benefits have lagged behind wage levels in the labour market (Ólafsson, 2001). In a sense, it appears that the expansion of occupational pensions provision has been linked to a decline in the value of pension schemes provided by the state (Evans, 2009: 14). 
But while the PAYGO system does involve the direct and immediate transfer of money from one part to another part of the population, financial markets do not play a relevant role (Huffschmid, 2010: 244). The marginal role of this pillar within the Icelandic model means instead that financial markets play a key function in the accumulation of funded provisions provided by the occupational pension pillars that dominate retirement provision in this country (OECD, 2008: 45). ${ }^{2}$ Workers' dependence on money as a means of payment due to the retreatment of social provision in the field of pensions (Lapavitsas, 2009: 132) was strengthened by the agreement between the government and the public employees' unions in 1997, and passed into law a few months later. From that moment on, all new state employees would become members of fully funded schemes with a similar system for accumulation of pension rights to that prevailing on the private market (OECD, 1999: 109-111; Gudmundsson, 2001; Herbertsson, 2005).

Indeed, the most significant deviation of the Icelandic pension system from that of other Nordic systems is the dominant role of occupational funded provisions as against common pay-as-you-go provisions based on assured or notional rights (Ólafsson, 1999; OECD, 2008: 44; NOSOSCO, 2010). The amount of pension benefits, in this system, depends on the performance of the financial markets, and means that the coverage of benefits to which workers are entitled is significantly shaped by the financial system. The regulation of occupational pension plans has played a key role in the development and the speculative direction of the Icelandic pension market. First, the fact that all wage earners and self-employed persons are obliged by law to subscribe to pension plans and to pay contributions to them helps to explain the exceptionally high coverage of occupational pension plans among the workforce in Iceland, which is over 90 per cent. This means that the pension market has benefited from disposable income revenue of virtually the entire employed labour force of Iceland. Second, the lack of a developed legal framework has given unions and employers complete control over pension funds, allowing them to quickly change and bend rules and regulations according to their own 'needs' (Baldvinsdóttir, 1998: 160). For some decades, while forcing workers to belong to and pay part of their income into funds, employers and trade unions could dispose of a considerable amount of money, which was lent back to members in the form of mortgages. ${ }^{3}$ With the crisis of the export-led regime of accumulation between the 1980s and 1990s, this investment strategy ceased to be sustainable. Due to that crisis, negative interest rates and the lack of profitable investment opportunities within the internal market were eroding the pension wealth of Icelandic workers. At that point, an agreement in 1995 between ASÍ and SÍ quickly removed many limitations regarding domestic shareholding as well as foreign investment in their total net assets. This agreement was promptly absorbed by the government, which in 1997 and in the following years officially allowed pension funds to achieve the best return-risk composition available at any given time (Guðmundsson, 2001: 6). Pension funds were legally permitted to invest up to 50 per cent of their assets in foreign stocks (which could in theory be extended to 100 per cent if the investments were hedged back into the Icelandic króna), up to 60 per cent in equities listed on recognised and organised exchanges (with 10 per cent in unlisted securities). Finally, no ceilings on mortgage bonds were provided. These measures facilitated the shifting of the asset allocation of pension funds to corporate equities and risky bonds, at the expense of safe government assets or loans to members. 
Table 1. Relative share of assets and members in DB- and DC-funded occupational pension plans

\begin{tabular}{|c|c|c|c|c|}
\hline \multirow[t]{2}{*}{ Country } & \multicolumn{2}{|l|}{ Assets } & \multicolumn{2}{|l|}{ Members } \\
\hline & DC Plans & DB Plans & DC Plans & DB Plans \\
\hline Iceland* & 82 & 18 & 92 & 8 \\
\hline Denmark & 97 & 3 & 50 & 50 \\
\hline Finland* & 0 & 100 & 21 & 79 \\
\hline Netherlands & 9 & 91 & 5 & 95 \\
\hline Norway* & 0 & 100 & $n / a$ & $\mathrm{n} / \mathrm{a}$ \\
\hline Sweden & 5 & 95 & 50 & 50 \\
\hline U.K. & 22 & 78 & 16 & 84 \\
\hline USA & 35 & 65 & 70 & 30 \\
\hline
\end{tabular}

Source. OECD Global Pension Statistics; ${ }^{*}$ Indicates mandatory coverage.

Last but not least, the very typology of the Icelandic occupational pension funds appears to have played a crucial role in pushing such funds' flow into speculative domestic and foreign markets, delinking them from its roots in real activity. The bulk of Icelandic occupational pension plans operate much like defined contribution (DC) schemes, being fully funded through accumulated payments where the translation of units into benefits is adjusted according to investment returns - as usually happens in the neoliberal countries. This is at odds with Continental Europe and Scandinavian social democracies, where defined benefit (DB) plans are far more common (OECD, 2008). Table 1 shows the estimates of the relative share of assets and members in DB and DC pension plans in Scandinavia and in two paradigmatic cases in neoliberal countries, namely the UK and the USA. Contrary to other Scandinavian countries (except for Denmark), defined benefit private pension assets in Iceland as a percentage of total occupational assets amounted only to 18 per cent in 2007, while more than 90 per cent of Icelandic employees belonged to such plans. At the end of 2007, 31 fully operational pension funds operated in Iceland, including 12 with employer guarantees from the state government, municipalities or banks. The remaining 19 funds, which cover the bulk of private-sector workers and public employees hired since 1998, are classified as DC.

Unlike DB plans, where the employer bears the risk that returns on investment may not be sufficient to meet guaranteed benefits, the DC system lacks any commitment to a set amount of benefits, meaning that participants bear the risk that returns from those funds will be sufficient to provide for their material well-being, security, and freedom in retirement. Employers' release of the risk of entirely financing possible insolvency as well as the lack of a specified monthly benefit on retirement that is predetermined, pushed them to adopt investment strategies that were more and more speculative. If fund assets are insufficient to achieve the necessary income flows with lower-return safe investments such as Treasury or high-rated corporate bonds, to earn higher returns pension funds must increase risk (Crotty, 2008: 20). This explains why members of DC plans typically invest for their future through equity-based mutual funds, whilst whether they receive high or low incomes depends in part on financial market forces (Langley, 2008: 67-69). 
Given that the main difference with the pure DC system is that in Iceland participants share in the investment risk en masse rather than as individuals, ${ }^{4}$ the result is that not only people but also trade unions are encouraged to think of themselves as shareholders in the great capitalist bonanza, rather than as members of mutual organisations or as citizens (Mellor, 2010: 66).

As a consequence of flows of money capital into the national and international financial markets, the Icelandic occupational pension funds experienced inflation, which caused asset values to rise by an average of 17.9 per cent per year relative to GDP during the period 2001-07. The importance of pension funds for the domestic financial market is highlighted by the ratio of pension funds' assets to market capitalisation. In Iceland, this ration equaled 152 per cent in 2003 - more than double that of three major liberal market economies, the USA (66 per cent), UK (65.7 per cent) and Australia (56.1 per cent), and significantly higher than in other Nordic countries - cf. Finland (7.9 per cent), Sweden (8 per cent) and Norway (10.7 per cent). The increase of pension funds' size and depth within the national stock market is a central factor underlying the financialisation of the Icelandic economy. To illustrate this, Figures 1 and 2 compare Iceland with other Scandinavian countries. Figure 1 charts stock market capitalisation. Here, the dramatic rise in the value of financial assets and finance-based income as a percent of GDP in Iceland from the late 1990s becomes quite evident, jumping from 7.7 per cent in 1994, a value that was the lowest of the countries under consideration, to near 220 per cent in 2006, which was the highest. In turn, money incomes and money stocks have become a systematic source of financial profit (Lapavitsas, 2009). Figure 2 gives the share of financial profits to total corporate profits. While remaining more or less steady in the other Nordic economies, Iceland's share has risen from just over 20 per cent in 1997 to a peak of 58 per cent in 2007.

The remainder of this article is organised as follows. The second section traces the origin of the Icelandic financial liberalisation to the collapse of the 'export-led growth'

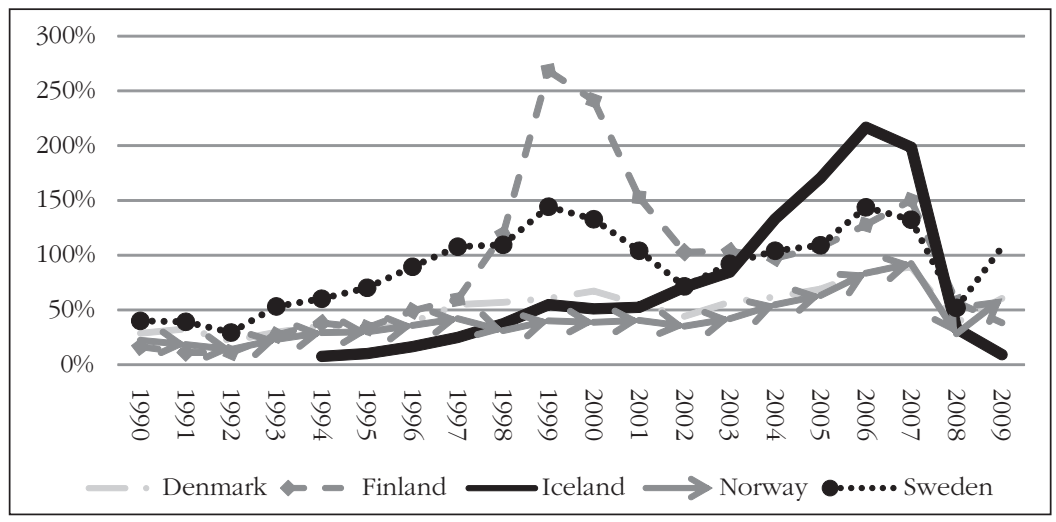

Figure 1. Financialisation of Scandinavian countries - Stock market capitalisation as $\%$ of GDP

Source. Author's elaboration based on OECD dataset.

Note. For Finland, the rise of market capitalisation to GDP in the late-1990s is chiefly due to Nokia, which had astonishingly high values in the period 1999-2001 (Allen et al., 2006: 95). 


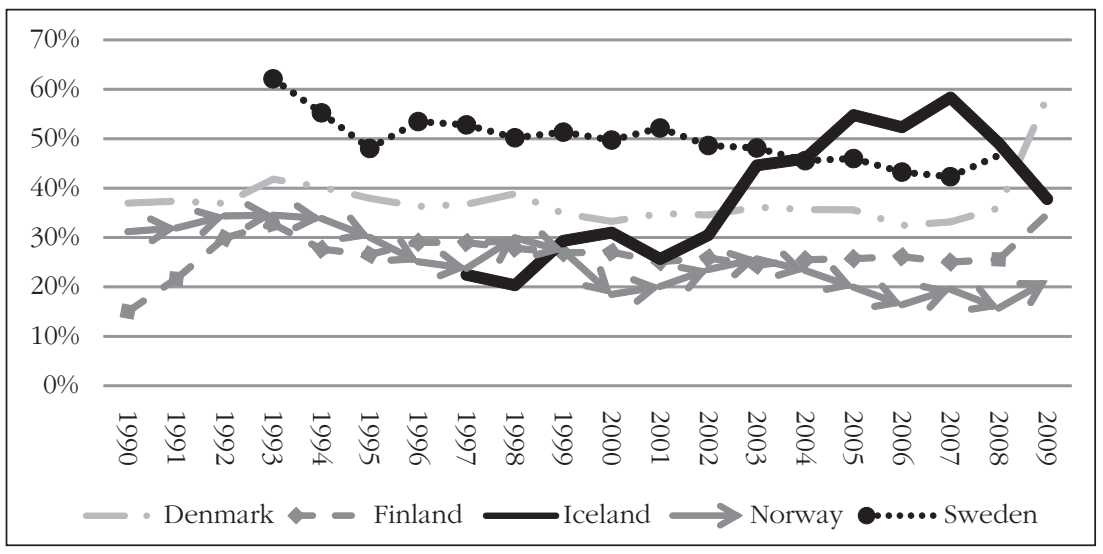

Figure 2. Financialisation of Scandinavian countries - financial / total profits Source. Author's elaboration based on OECD dataset.

accumulation regime. I then analyse trade unions' involvement in a neo-corporatism pattern from the late-1980s on. Here, I examine how trade union cooperation with employers and the state was an essential condition to the defeat of the record conflictuality (and thus the sky-high inflation) from the Icelandic socioeconomic environment, laying the foundations for the necessary institutions, which were capable of absorbing enormous masses of capital from the rest of the world. In the fourth section, I analyse the way the immersion of trade unions in financial mechanisms through the pension industry created a broad consensus around the 'stabilisation programme' accomplished by the neoliberal governments since the early 1990s. An examination of pension funds in the neoliberal compromise follows, where I discuss why the dual nature of the trade unions as a financial operator on the one hand, and as a workingclass organisation on the other, has become more and more difficult to conciliate. In the light of this finding, in the fifth section I finally investigate the use of the Icelandic workers' pensions to rescue the national financial system after the banking meltdown in 2008.

I start from the assumption that economic structure firstly shapes the social, political and juridical over-structure. Then, the balance of power of social and political forces that arise from the direct relations of production strongly affects the reproduction and transformation of the economy. In this connection, it is fundamental to determine how the led-export regime of accumulation's crisis in the late-1980s interacted with the redefinition of the labour-capital relations in which the capacity for economy and labour market regulations started to be highly dependent on the coordination between collective actors and the state. In this respect, choices and discretion on the part of labour, management and government affected the same course and structure of industrial relations systems (Kochan et al., 1984). But if the functionality of macro-economic governance did not determine the fate of industrial relations, then the structures of industrial relations themselves seemed to have played the key role in determining the direction of adjustment (Traxler, 2003: 150). 


\section{The roots of the financialisation of the Icelandic economy}

From the early days of its industrialisation, Iceland's development path was characterised by one-sided export specialisation and a fairly passive adjustment to international markets (Ólafsson, 1981; Magnússon, 1985; Jónsson, 1991, 2004). The great openness of the economy affected the role of exchange rates in the sense that throughout the postwar period, both the conservative and social-democrat governments repeatedly emphasised the devaluation of the currency as an anti-cyclical policy instrument to prevent the profitability of its export industries, mainly in the fish sector, ${ }^{5}$ from being unduly eroded by inflation (Gylfason, 1990: 167). ${ }^{6}$ Besides preventing productivity growth in both the fishing and manufacturing sectors, this strategy made the economy extremely vulnerable to fluctuations in the resource-supply and foreign markets, causing huge variation in incomes and investment, and putting a strain on its macro-economic policy.

Since low productivity, inherent to the Icelandic model, required a very high level of labour utilisation (OECD, 1997: 103), the government had to conciliate two contradictory goals: guaranteeing profits for fish exporters while maintaining full employment. In this regard, the method that the policy makers often adopted was to use both numerical and wage flexibility as a buffer against external shocks (Jónsson, 1991, 1995; Eðvarðsson, 2003). As Figure 3 illustrates, during the period 1953-1989, real wages responded quickly to economic fluctuations, by increasing in the wake of favourable shocks despite less than the GDP growth - and declining following adverse shocks - albeit much more than the GDP decrease. The result of this policy was that, while GDP output and real wages had a volatile but pro-cyclical trend, real-wage flexibility has reduced the employment effect of macroeconomic shocks (Agnarsson et al., 1999: 17). ${ }^{7}$

The extreme volatility of the economy prior to 1990 greatly boosted social instability in Iceland due to the fact that employment relations were not isolated, but had to adapt in reaction to the changes in international markets. Despite resembling the other Nordic

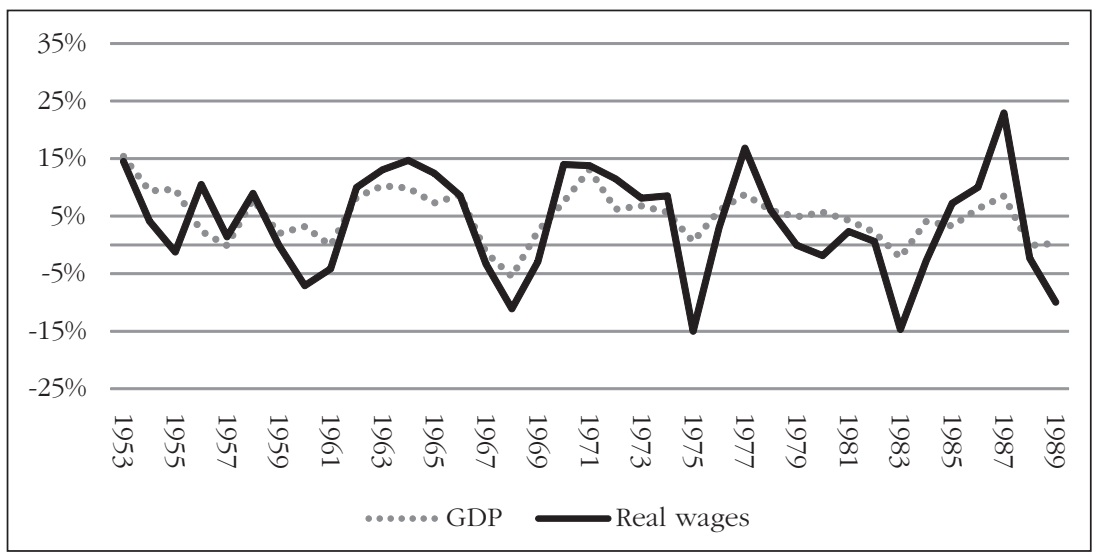

Figure 3. GDP and real wages - growth rates (1953 - 1989)

Source. Author's elaboration based on Iceland Historical Statistics. 
Table 2. Labour conflictuality in Nordic countries: days lost per 1000 employees

\begin{tabular}{lcrccc}
\hline Period & Denmark & Finland & Norway & Sweden & Iceland \\
\hline $1960-64$ & 227.0 & 154.0 & 106.0 & 4.6 & 1706.0 \\
$1965-69$ & 31.7 & 83.1 & 7.6 & 19.7 & 1198.0 \\
$1970-74$ & 360.0 & 597.0 & 53.4 & 55.8 & 1056.0 \\
$1975-79$ & 72.2 & 385.0 & 28.7 & 26.8 & 1278.8 \\
Average 1960-79 & 172.7 & 304.8 & 49.0 & 26.7 & $\mathbf{1 3 0 9 . 7}$ \\
\hline
\end{tabular}

Source. Author's elaboration based on LABORISTA database; Aðalsteinsson 2007.

systems of industrial relations - which are commonly associated with a very high regulation potential - compromise between labour and capital in Iceland did not function because the same institutions could not protect it from pressures in the market (Líndal, 1995; Magnússon, 1995; Dølvik, 2008). Different from other Nordic systems, devaluations in Iceland took the form of national wage restraint and competitiveness, without the need for neo-corporatist agreements (Kristjánsson, 1977; Jónsson, 1995; Guðmundsson and Kristinsson, 1997). However, after the devaluations, profits skyrocketed, while imported inflation eroded real wages. As economic conditions improved, strikes followed as wage earners tried to compensate for their losses (Mjøset, 2000). As Korpi and Shalev (1979: 186) pointed out, endemic conflictuality has characterised the Icelandic labour movement all along. By measuring the intensity of class struggle by thousands of working-days lost in strike activity, Table 2 shows how conflictuality in Iceland was historically much higher than that of other Nordic countries, averaging 1309.7 working days lost during the period 1960-1979, almost fifty times higher than that of Sweden, more than twenty-five times more than in Norway, four-and-a-half times more than in Finland, and almost eight times higher than that of Denmark.

The collapse of the Bretton Woods exchange rate system in the early 1970s and the unfavourable terms of trade at the end of the decade (mainly due to increase in oil prices) rang the alarm bell of the Icelandic export-led regime of accumulation. Since then, the Icelandic routines of devaluation policy led to a boost in inflation, due to the tight labour market and the strong militancy of the Icelandic working class, which frustrated the government's attempts to permanently abolish the index-linking of wage formation in order to secure profits in export sectors. The net result of these developments was that each successive shock in the 1970s and early 1980s led to successively higher inflation peaks (Guðmundsson, 2002: 19), accelerating the wage-price spiral. Along with a repressed financial system that lacked markets for securities, this caused the real lending rates as well as the real deposit rates to often be negative. While giving borrowers a substantial subsidy, this situation punished those who deposited their funds in the banks. In response, the latter substituted bank deposits by trying to store their wealth in physical assets, creating a financial crisis for producers and others who relied on bank credit. As expected, the domestic financial system sought relief through foreign borrowing and relending at home. The USA's turn to tight monetary policies in 1979 worsened the situation, making inflation explode to 59 per cent. By taking the decision that deposits should bear positive real interest rates in order to restore the stock of financial saving, the government in 1980 introduced general indexation of financial obligations, including bank deposits and bank loans (Eggertsson and Herbertsson, 2005: 13-15). At the same 
time, the high levels of wages and prices led to fast increases in costs of production, which led to an increased willingness of capital in the trade and fish sectors to collaborate (Jónsson, 1995: 135-40) in order to reduce inflation, mainly through a repressive intervention in the labour market that was very similar to the so-called 'heterodox' programmes adopted in many high-inflation countries in Latin America during the mid1980s (Andersen and Guðmundsson, 1998: 13). During the 'blitzkrieg against inflation' of 1983-1984, the centre-right government that represented those interests ferociously cut back workers' rights to bargain and to strike, bringing the rate of inflation down from 82.1 to 31 per cent in only one year, while the share of compensation of employees in the GDP decreased by 7.1 per cent. On the monetary side, in order to stabilise the currency, the government abolished its control over interest rates, allowing the banks to decide their levels. As a result, real interest rates almost doubled in only three years. In view of this and the connections between the pension funds and at least some of the banks, it is not surprising that the pension funds started to invest increasingly in bank bonds at that time (Baldvinsdóttir, 1998: 141)

The relatively favourable development of the costs of production due to the suppression of the real wages as well as of the great increase in marine export prices in 1986 and 1987 made it temporarily easier for fish-sector capital to accept the high-interest-rate regime, leading to a situation in which claims for currency devaluation (to sustain its profitability) were not necessary. Moreover, enormous investment in the fishing sector in 1985, mainly financed with foreign loans, as well as a general increase in long-term foreign debt and debt burden, marked increasing problems of using devaluation as a mean to secure the profitability of exporting sectors. ${ }^{8}$ For all these reasons, the fish sector was satisfied with policies of fixed exchange rates as long as wages and inflation were kept down and terms of trade were favourable (Jónsson, 1991: 340-341). Yet with the slowdown in the fisheries' catch in 1987 and the increase in foreign and domestic interest rates, the debt burden became increasingly critical for the firms in the fish sector. This means that, when the international credit crunch crisis of 1988 came and real export revenue contracted, the Icelandic fish sector was hit hard, swiftly subverting the collaboration between trade and fish-sector capital. The governments in charge from July 1987 and September 1989 used the same tools to face the economic crisis and to revitalise the exports, i.e. currency depreciation, and anti-labour policies. ${ }^{9}$ After the króna was devalued by 16 per cent between February and May 1988, the government adopted a measure to reap the full benefits of that devaluation by restricting the right of worker organisations to engage in free collective bargaining and prohibiting the right to strike. ${ }^{10}$ Although the government kept trying to manage the labour movements through very repressive interventionist forms, the Icelandic working class did not peacefully come to accept the long-term redistribution of income in favour of business. In addition to the historical industrial relations' inability of guaranteeing cooperation between labour and capital, the fact was simply that 'under a regime of full employment, the sack would cease to play its role as a disciplinary device' (Kalecki, 1943a: 351). As late as 1988, just as it was through the 1980s, the rate of inflation in Iceland was 25 per cent, still well above that of its main competitors (Figure 4).

As a result, the fiscal deficit increased significantly whereas the competitive position deteriorated by more than 17 per cent between 1984 and 1988 (Guðmundsson et al., 2000: 9). This, combined with the rapid growth of domestic demand, led to a further 


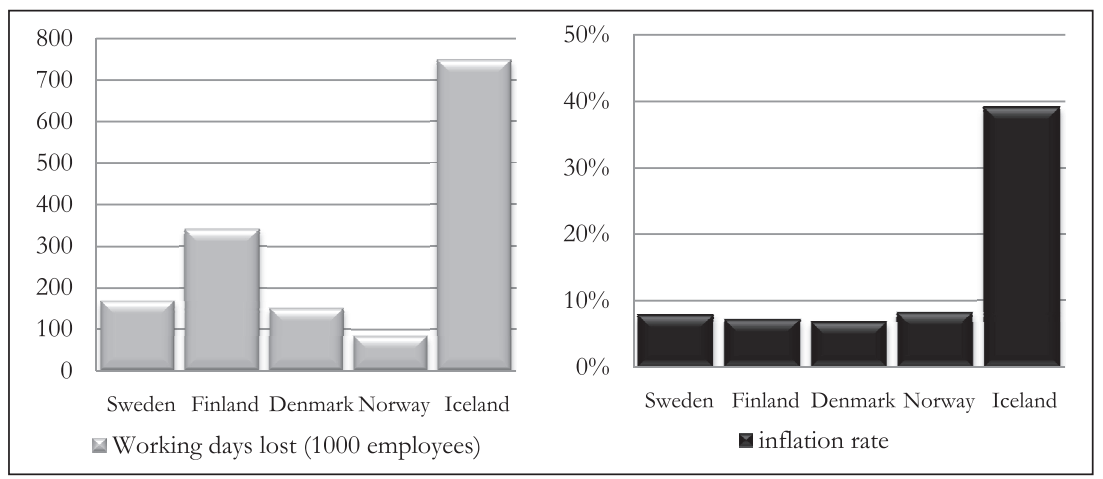

Figure 4. Strike activity and inflation rate in Nordic countries (1980-1989, average) Source. Author's elaboration based on ILO and World Bank dataset.

widening of the current account imbalance and a progressive build-up of foreign liabilities (Andersen and Guðmundsson, 1998: 12), making devaluation strategy even more difficult to protract. Or to put it another way, the goals of matching a satisfactory profitability in the fisheries sector with a restraint on inflation seemed to have become incompatible. The only way to come out of this impasse was found in the shifting of priority in the trade-off between full employment and low inflation: if during the postwar period this dilemma was resolved in favour of employment, since the late-1980s the social actors and governments resolved it by favouring price stability, and by institutionalising the conflict between capital and labour in order to restore capital accumulation.

\section{The social prerequisites of the financial accumulation regime}

The recession in 1988 was the driving force behind a fundamental shift in attitudes among trade unions, employers and the state towards the need to correct the structural imbalances of the Icelandic economy and to remove the threat they posed to inflation stability (Óskarsdóttir, 1997; Jónsson, 1991). Coinciding with these shifts was also the realisation that devaluations not supported by a consensual incomes policy to manage the relationship between the labour market and the economy would have short-lived real effects. Hence, one important part of this stage was a significantly lower devaluation bias, with the most visual effect of that reorientation being the fundamental change in the labour market (Andersen and Guðmundsson, 1998). Following the crisis in 1988, it now became possible for ASÍ to deter individual unions and federations from pursuing militant wage strategies, convincing them that it was more convenient to move from a zerosum type of conflict to a positive-sum type, where both parties could expect to gain from cooperation to increase economic growth. ${ }^{11}$ In this respect, the centralised authority of ASÎ's leadership provided coherence of aims against the fragmentation of policies and actions between and within the unions, by limiting the capacity of individual unions to free-ride on the wage restraint of other unions (Iversen, 1996: 405). Also, the employers' association (SÍ) supported the centralisation of negotiations due to its inability to cope 
with the political consequences of full employment and the growing discontent over the distributive consequences of decentralising the bargaining system (OECD, 1997: 119): in 1989, although real wages were decreasing by 9.1 per cent, working days lost in the private sector fell to 2,250 from 100,773 in the previous year. Finally, by reducing conflictuality, the three main conditions for a corporatist framework's implementation with the goal of coming out of the vicious circle of inflation were present: high degrees of both organisational centralisation and associational monopoly (Schmitter, 1981), the participation of interest organisations in public policy-making (Lehmbruch, I984), and the commitment to a 'social partnership ideology' in economic policy areas (Schmidt, 1982).

Under these premises, and after it was decided to keep the currency stable against a trade-weighted basket of seventeen currencies, ${ }^{12}$ in 1990 the ASÍ, Sí and the socialdemocratic government signed the 'National Agreement', setting the trend for a new neo-corporative labour-relations era. After the government convinced the labour unions that they should believe in inflation predictions rather than looking at past inflation (Andersen and Guðmundsson, 1998: 16), the collective agreement in February 1990 which was to be in effect for a record length of twenty months - predicted that wages would only increase according to negotiated 'red lines' and that individual groups should not get more than other groups, so that the structure of income differences between groups would not change (Jónsson, 1991: 192). To ensure this provision, the government issued provisional laws in order to defend the National Accord, which specified how much all wages in the country were allowed to increase. Thanks to these measures, the nominal wages increased by nearly 10 per cent when the rate of inflation was running above 14.5 , pushing real wages down by 4.9 per cent.

The new rounds of collective bargaining that came underway in 1992 and 1993 emphasised the need to continue to cooperate in cutting down inflation but also to reduce unemployment - which in the meantime had reached an unprecedented high level. By this time, however, the attack on salaries was more direct. These agreements were stipulated under the promise to keep the currency's value unchanged and to try to influence interest rates in the hope of making them come down (Óskarsdóttir, 1997: 160). But a few months after the agreements were signed, the government decided, first in the wake of turmoil in the European foreign-exchange markets and then at the urging of employers in the fishing industry, to depreciate the króna by 6 per cent in November 1992, and by 7.5 per cent at the end of June 1993. In addition, the government decided to lower taxes on companies, whereas taxes on the public were increased. ${ }^{13}$ The shock treatments worked well, enabling the central goals of the trade unions, employers and governments: to lower inflation and stabilise the currency, which were finally reached, when in the fourth quarter of 1994, the rate of inflation plummeted to 0.4 from 21.1 per cent in 1989, allowing a long period of exchange-rate stability to begin. The shift from high-employment policies to price-stability strategies responded to the business leaders' class instinct, according to which 'lasting full employment is unsound from their point of view' (Kalecki, 1943a: 351). Kalecki's intuition also fits for the Icelandic case, where the fall in labour's share in the first part of the 1990s went together with rising unemployment (Zoega, 2002: 12). During the 1990-1995 period (Figure 5), real wages were cut more than 7 per cent and unemployment reached an unprecedented 6 per cent in 1995, whereas the labour participation rate dropped from over 80 per cent to 76 per cent. This made the share of the compensation of employees on the GDP to fall by more 


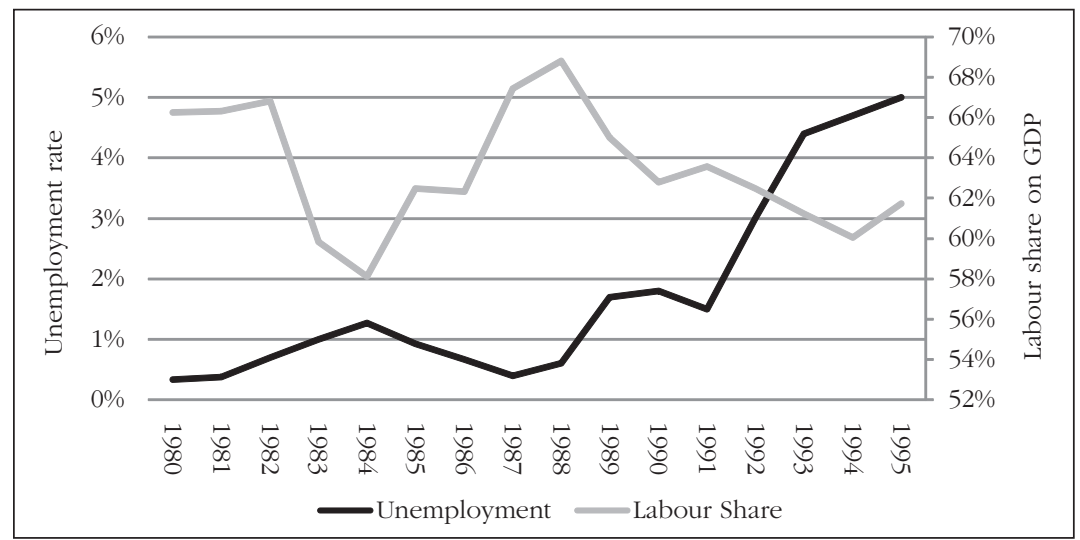

Figure 5. The share of labour on GDP and the unemployment rate Source. Author's elaboration based on Iceland Historical Statistics.

than 5 points, whereas the operating surplus of Icelandic companies increased from 20.2 per cent to 23.4 per cent of GDP.

Despite the massive redistribution of income in favour of profits, the consumption in fixed capital - and by implication real economic activity, held steady due to lower prospects for profit rates in productive and commercial sectors in comparison to the general rate of interest - entered into a phase of endless increase. The latter was fuelled by the liberalisation of long- and short-term capital movements in 1994 and 1995 that made the further raising of interest rates inevitable in order to prevent capital outflows as well as to attract new foreign investors. Due to the high cost of the króna, new investments - whose ratio to GDP averaged 28 per cent in the 1970 s and more than 20 per cent in the 1980s - fell less than 17 per cent in the 1990s. At the same time, the drop in investment implied a fall in productivity which moved down from 3.5 per cent in the 1970s to only 1.2 per cent in the 1990s. The outcome was that from the early 1990s onwards, the leading sector of the Icelandic economy, i.e. the fish sector, lost its competitiveness compared to other Nordic economies, its direct competitors in international markets. ${ }^{14}$ On the other hand, the manufacturing sector continued to be dominated by very small firms and low levels of concentration and centralisation of capital, lacking productivity gains (OECD, 2005: 32)..$^{15}$ The stability of the exchange rate, low inflation and a high interest rate differential vis-à-vis international markets provided many profitable opportunities in the financial sector, as the interest shown by foreign and domestic investors in the domestic money and securities markets had increased significantly (Guðmundsson and Kristinsson, 1997: 68). This led the gross value added in this sector to an incredible growth during the period 1990-2006, much higher than other Nordic countries. The process of 'creative destruction' - that is emigration of investments out of less profitable sectors, i.e. fishing and manufacturing sector, and immigration into a more profitable one, i.e. finance - transformed the country's economic landscape, which changed through the disappearance of former leading firms, mergers, and the arrival of newcomers (Eggertsson and Herbertsson, 2005: 2), relegating the fisheries to a back seat in the minds of many Icelanders (Benediktsson and Karlsdóttir, 2011: 230). In the 1990-2007 


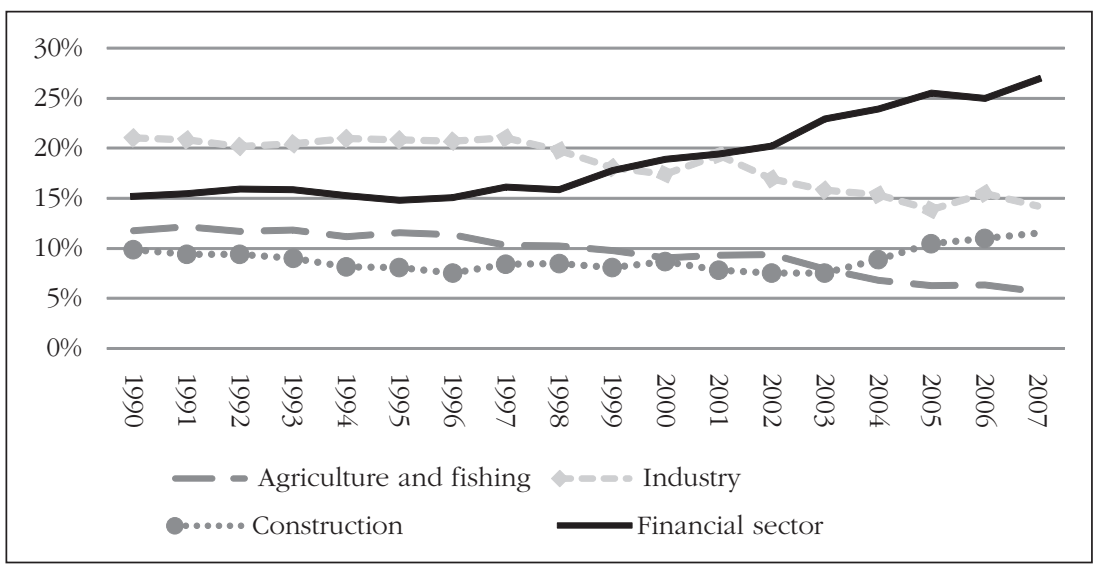

Figure 6. Gross Domestic Product by economic activities 1990-2007 (\%) Source. Author's elaboration based on OECD dataset.

period, while the weight of the primary and the secondary sectors on the GDP almost halved, finance grew in size relative to production, with the GDP share in the banking and finance sectors increasing from 15.2 to 27 per cent (Figure 6). Meanwhile, the GDP ratio in other services remained quite stable, fluctuating between 42.4 and 41.6 per cent.

The impressive performance experienced by the Icelandic economy from the late1990 s was sustained by a very strong credit boom that was to a significant degree financed by foreign borrowing. The latter was in turn fuelled by the policy of exchange-rate stability and explicit and implicit government guarantees of the banking system. The increased degree of competition for market shares among financial institutions that accompanied the start of the privatisation process in 1998 gave the credit boom a further boost (Stiglitz, 2001: 30). ${ }^{16}$

It is worth noting that neo-corporatism, by reducing endemic conflictuality, greatly concurred to lay the foundations of the financial institutions that have boosted the Icelandic economy since the late-1990s. With the National Accord in 1990 and the agreements that followed, the Icelandic working class went from being one of the most combative to becoming one of the quietest in the world. The socioeconomic stability enhanced the national economic 'credibility' that, combined with the liberalisation of the financial market, helped the internal market to attract foreign speculators as well as to gain access to loans from international markets (Screpanti, 2001). In turn, inflation tendencies due to the massive capital inflow were met by the government by further raising short-term interest rates, which attracted more foreign capital, leading the króna to appreciate and therefore encouraging banks and other financial institutions like pension funds to borrow cheaply and buy assets abroad, transforming the revenue streams into dramatically higher profits, wages, tax revenues and political support at home (Wade and Sigurgeirsdóttir, 2011: 58).

Yet, intermediation had not neutralised nor subverted struggling interests between capital and labour in Iceland, due to the incapacity of industrial management to secure the active consent of the labour force employed in the sector worst hit by economic 
restructuring: the fishing sector (Eythórsson 2000). By giving permission for the transfer of quota shares between vessels with different owners, ${ }^{17}$ the reform of the Individual Transferable Quota (ITQ) in 1991 removed the opportunity for fishing communities to earn income from fishing, with the result of a massive re-distribution of wealth and income (Árnason, 1992, Knútsson and Gestsson, 2001). Over time, the quota system resulted in increased profitability and considerable wealth creation, which became one of the main pillars in the subsequent banking-based economy (Daníelsson and Zoega, 2009: 4). Nevertheless, the new ITQ system became also one of the main reasons for the renewal of the conflict in the labour market. ${ }^{18}$

However, in controlling a strategic branch of the national economy, the ITQ owners were in a strong position, which allowed them to put pressure on the government to reform the regulation of labour relations, aiming to provide more stringent conditions to call for strikes. Starting from the belief that the new ITQ system was the 'best resource management system in the world', ${ }^{19}$ the position of ASÍ's leadership was very supportive: 'the making of free contract without any troubles gives stability and social peace. The question is how to reach this goal'. The agreement between the 'social partners' and the government concerning the keeping of social peace in the fish industry laid the way for the drastic reform of industrial relations in the country in 1996 (Act no. 75), with the purpose of speeding up negotiations between the federation of the employers and labour unions to improve the functioning of the market (OECD, 1999: 81). The way to this goal was found, on the one hand, by fixing special, stringent conditions for strike declarations, and on the other, by imposing compulsory arbitration when the parties did not reach agreement, or when a certain number of days of strike had elapsed. Therefore, on the pretext of speeding up the bargaining process, the government created a juridical organism clearly tied to political power and hence submitted to its political and economic targets.

Table 3 displays the conflictuality level, the rate of inflation, rate of interest, union density, and GDP growth since 1980. In the first period, from 1980 to 1989, the endemic conflictuality was coupled with an inflationist spiral, which in turn was reflected in negative real interest rates. The socioeconomic setting drastically changed after 1990. From this year, the decline of strike activity - it decreased by 84 and 96 per cent compared to the two previous decades - resulted in a substantial drop of inflation, at 35 points lower compared to the previous periods. As a consequence, and due to the

Table 3. The socio-political construction of monetarism

\begin{tabular}{llllll}
\hline Period & $\begin{array}{l}\text { Working days lost } \\
\text { (private sector) }\end{array}$ & $\begin{array}{l}\text { Trade union } \\
\text { density }\end{array}$ & $\begin{array}{l}\text { Rate of } \\
\text { inflation }\end{array}$ & $\begin{array}{l}\text { Real interest } \\
\text { rate }\end{array}$ & GDP growth \\
\hline $1980-89$ & 21.857 & 68,2 & 39,3 & $-2,8$ & 3,2 \\
$1990-99$ & 3.507 & 80,9 & 4,2 & 8,4 & 2,3 \\
$2000-07$ & 946 & 87,5 & 4,7 & 10,5 & 4,4 \\
\hline
\end{tabular}

Source. Author's elaboration from OECD dataset and Statistics Iceland.

Note. Real interest rate is the lending interest rate adjusted for inflation as measured by the GDP deflator. 
liberalisation in financial-market transactions, real interest rates shot upwards, to 8.4 and more than 10 per cent during 1990-99 and 2000-07 periods, respectively.

Besides the reform of labour relations and the establishment of very long agreements between unions and employers' associations, ${ }^{20}$ the radical decline in the militancy of Icelandic workers may be found in the same monetarist criteria adopted since the mid1990s, in which employees were 'forced' to go into debt as well as having to redirect their savings towards the financial markets, therefore reinforcing the risk that control over labour was enhanced via the volatility of financial markets (Bellofiore and Halevi, 2008: 3-9). On the other hand, a Central Bank of Iceland reform that introduced inflation targeting' in 2001 whilst raising interest rates, had the effect of further disciplining the workers: from that moment on, wage increases had to be at a level compatible with the inflation target. Otherwise, any wage requests advanced by the unions that were higher than the monetary expansion announced by the Central Bank would have generated unemployment, and therefore would have been irrational. The implication was that any conflicting behaviour adopted by the trade unions in order to obtain wage gains would have been self-defeating for the workers. ${ }^{21}$

What is most surprising in the above table is the union density column: contrary to what one might expect, this variable has seen a growing trend by almost 20 points, making Iceland the country with the highest union density in the world. This means that economic liberalisation did not replace the organisations with the 'market'; that is, it did not push towards the disorganisation of labour relations, as the prevailing governance mechanism. While trade unions are almost universally on the defensive, having suffered a decline in membership, in public status and in effectiveness in achieving their core objectives (Hyman, 2007: 195), Icelandic labour unions seemed to have resisted the neoliberal march. This has been so despite the fact that also in Iceland conservative and market-oriented governments have been in power for most of the last twenty years, accomplishing a process of strong liberalisation. On the other hand, by increasing its membership and influence on Icelandic society, ASÍ became one of the major economic and political players in the country.

The impressive economic growth experienced by Iceland from the late-1990s, besides lowering unemployment, allowed ASÍ to achieve improvements in real wages and social benefits that had the effect of satisfying members' expectations which, in turn, strengthened its social and political legitimation. On the other hand, due to the great credibility and status of ASÍ leaders among the employers and the government - and their shared interests - neoliberal coalitions had fewer reasons to fight the trade unions. This strategy, however, presumed that this type of economic growth was sustainable and that, although in a context of capitalistic compatibilities, it would also conciliate its members (workers) demands to governmental and employers requests. The economic crisis that began in 2008 revealed that such conciliation of interests was very ephemeral and that in reality, Icelandic workers were embedded into a speculative economic growth. To put it bluntly, the truth behind the Icelandic miracle was that the huge indebtedness worked like a drug deliberately injected into the system with the express aim of masking a latent profitability crisis in the fish sector, sustaining a restructuration that could not be sustained. Once the bubble burst, this untenable regime of accumulation was quick to show its real substance, or lack thereof. 


\section{The missing link between the consensus of the labour unions and the financial elite: The occupational pension funds}

The consensus of the Icelandic unions concerning the new wave of neoliberal policies did not rely only on ideological reasons. Rather, the common view on the macroeconomic goals shared with neoliberal coalitions and financial elite needs to be understood in the light of the fact that the ASÍ was not only a defense institution for the interests of the employees, but also an 'institution of money' (Minsky, 1982) whose main goal was to seek profits. More specifically, the real cause at the bottom of the acceptance of restraint policies, which has paved the way for the liberalisation of the economy since the early-'90s, was that ASÍ was heavily involved in the management of a financial entity, namely the occupational pension funds.

The origin of the pension fund scheme goes back to the Independent Party-Social Democratic coalition in the 1960 s, when ASÍ experienced a democratic internal involution due to its entering the central committee of people linked to each political party, not just those of the left (Kjartansson, 1992: 233). Conversely, the conservative influence within the labour movement grew enormously during the same period. Moreover, the IP's relationship with employers and the combined IP-SDP trade union strength created networks of interests that, by linking together the leadership of the major social and economic interests of the system, reduced the potential conflict between capital, labour, and the state. ${ }^{22}$ It was within this context that a comprehensive private pension fund scheme - under the joint control of trade union leaders and employers' associations was established, following a tripartite collective agreement between the social actors and the state in 1969. While the goal of the employers was to increase national savings in order to supply long-term finance in the capital market for the development of their businesses (Toporowski, 2000: 51), the ASÍ leaders believed that the pension funds mainly invested into the newborn People's Bank, which was under the direct control of ASÍ - would promote a more equitable political economy, reversing the social consequences of the crisis that had hit Iceland towards the end of the 1960s. They thought that in increasing the labour movements' influence in controlling the funds, strengthening their bargaining power and helping workers to gain access to capital, a 'labour control' of the accumulation process would have been enabled (Skýrsla forseta ASÍ, 1969/1972: 130-31).

Over time, the value of pension assets was increasingly depreciated by inflationist tendencies due to the impasses brought about by the export-led regime of accumulation (see section 1). In response, the composition, priorities, tactics and original strategies of ASÍ officials regarding the economic use of the pension funds changed. Whilst capitalists continued to use the biggest quota of national saving to expand their profits, the trade unions had to find new solutions to rapidly restore the value of the pension assets they controlled along with employers. Until the mid-1970s - when the 'export-led growth' regime of accumulation guaranteed high economic growth - unions could struggle for both expansive policies beneficial for productive investments and full employment, despite the inflationary bias of this regime. At the end of the decade, however, high inflation - and thus negative real interest rates on deposits - depleted the assets of the 
pension funds. But thanks to the introduction of financial indexation in 1979, free interest rates in 1986, and the positive economic conjuncture until 1987, the pension funds greatly rebuilt their assets. Until the liberalisation of market transactions with the entrance of Iceland into the EEA in 1994, the pension funds were mostly invested in safe domestic fixed-income securities, predominantly with government guarantees, and a significant part of them went to finance the public housing loan system, and to lend directly to their members. Variable income securities were only at 4.5 per cent, and foreign assets were at 1.9 per cent (Figure 7 ). When the 'devaluation strategies' could not work anymore, as debt burden became increasingly critical, the unions and employers who managed them along with the financial sector lobbied successfully to create those structural conditions - low inflation (or wage repression) and stable currency exchange - in preparation for the relaxation of financial restrictions, allowing these funds to find new channels to invest in, in order to look for the most cynical and opportunistic ways to the highest yields, to serve the interests of their members (Lipietz, 2000: 30). If until then the investment options of pension funds had been limited because of the repressed financial system - where no formal markets for bonds and equity existed, and the purchase of foreign securities was forbidden - the liberalisation of the economy became a more appealing option: in fact, due to the depressing state of the economy, it was clear that the domestic economy could never provide an investment platform for pensionfund capital (Sigurjónsson, 2009: 63). By being one of the biggest savings institutions in the country, and therefore one of the most powerful economic players in Iceland, the occupational pension funds played a central role in laying the foundation of financialisation of the Iceland economy. As Eggertsson and Herbertsson (2005: 18) pointed out, 'Prior to the liberalisation of the financial system the pension funds had very few choices for properly investing their funds .... However, the coincidence of the new pension system and liberalisation of financial markets had powerful interactive effects .... The strong demand by the pension funds for financial instruments combined with new opportunities for supplying securities was the catalyst that in the 1990s rapidly triggered a vibrant market for securities in Iceland.' As can be seen in Figure 7, the composition of pension funds' portfolio has changed dramatically since 1995 . At the end of 2005, fixed income securities were down to 49.1 per cent, housing bonds were down by more than half, and lending to members was a little less than 8 per cent. On the other hand, the share of equity had increased to over 48 percent, whereas the proportion of foreign assets, that was less than 2 per cent in 1995 , rose to 24.7 per cent ten years later, and the bulk of them were in the form of equity and shares in open-end and closed-end mutual funds.

The existence of a very objective, materially grounded reason for relevant members of the working class to cooperate with the capitalist class to impose anti-inflationary policies does not require the decision-making processes of unions to be conceived of in a strictly deterministic and unidirectional way. As Engels (1972: 294) puts it,

The economic situation is the basis, but the various elements of the superstructure - political forms of the class struggle and its results, to wit: ... juridical forms, and even the reflexes of all these actual struggles in the brains of the participants ... also exercise their influence upon the course of the historical struggles and in many cases preponderate in determining their form. There is an interaction of all these elements in which, amid all the endless host of ... the economic movement finally asserts itself as necessary. 


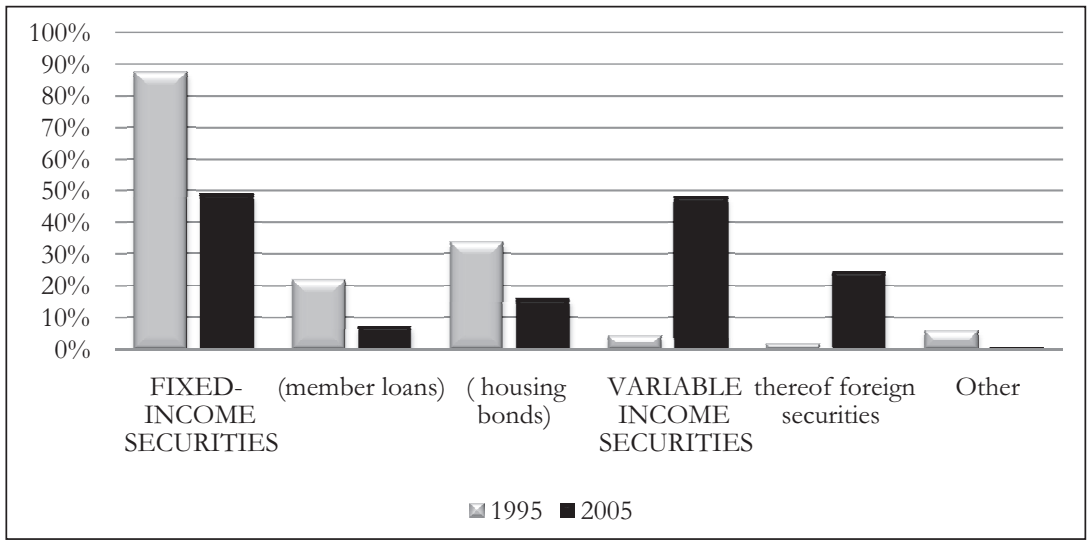

Figure 7. Pension funds' assets (1995-2005)

Source. Author's elaboration from Central Bank of Iceland data.

Structure and agency are as a rule dialectically related, and in this case trade union support for neoliberal policy boosting financial yields was contained in potentiality within the capitalist property form of the pension funds themselves. Given that the determined phenomenon is potentially present in the determinant one, and given that the determinant (realised) phenomenon has a specific contradictory social content which it received ultimately from the ownership-relation, the determinant phenomenon calls into existence the determined one, and thereby transfers to it its own contradictory social content (Carchedi, 2008: 500). In concrete terms, the joined ownership-relation on occupational pension fund appears to have united two essentially divided groups, transferring to the new 'actor network' which manages this financial institution its own contradictory social contest. The lack of rules about how much time each member could sit on the pensions board means that many of the same unions, employers' leaders and pension funds managers have occupied these positions for extended periods of time. The significance is that linkages and cooperation, developed over time, can be reasonably expected. The increasing involvement of pensions in the investment system of the country reinforced those links, creating a vast and complicated network of personal, financial and interlocking directorships, leading to concentration and centralisation in the financial sector and in the corporate community (Baldvinsdóttir, 1998: 270). As Baldvinsdóttir suggests, ASÍ has not only 'potential' financial strength, but a real one. The inner circle of ASÍ is on the board of directors of equity funds, security firms, leasing companies, state funds and credit card companies. There are many examples of figures who linked the labour movement, the employers association, the pension funds, the political and the financial systems:

Benedikt Davíðsson the president of ASÍ during the period 1992-1996, and Gunnar J. Friðriksson from Sí, served as chairmen of The Association of General Pension Funds continuously during the period 1983 -1995. They also were on the board of The People's Bank and the Industrial Bank, and Guðmundur H. Garðarsson from the National Association of Pension Funds was on the board of the Bank of Commerce. These three men are extremely 
influential within the pension fund industry, the labour movement (ASÍ) and the Federation of Employers. Furthermore, it should be noted that these same three men have been key members over the last 30-40 years in collective bargaining negotiations between ASÍ, Sí and the state. Hence, they created strong links between the pension fund industry, the private banks, the labour movement and the SÍ. (Baldvinsdóttir, 1998: 164-165)

The parallel development of banking and pension systems materially supported the establishment of this cooperation and these linkages. During the 1960s, the foundation of the three new private banks - two of them heavily tied to ASI and the biggest pension funds of the country - was made possible by the liquidity provided by the pension funds. The institution of the pension funds was thus, in many ways, the pre-condition for the establishment of the banks, with pension fund money providing the backbone for these banks. Moreover, with the steadily growing funds in the pension fund industry, all the private banks established even stronger ties between them and the pension funds, and all key members on the board of the pensions funds have been or are on the board of directors of the banks (Baldvinsdóttir, 1998). This complex of interactions resulted in the redefinition of the banking system in the aftermath of the systemic crisis of the fishing industry that swept the state-owned Fisheries Bank in 1987 (up to this moment the biggest financer of the primary sector). At that time, the credit institutions controlled by the labour movement, the employers and the biggest Icelandic pension funds - respectively the People's Bank, the Industrial Bank and the Bank of Commerce - joined together and at the same time took over the shares in the Fisheries Bank. Out of this merger emerged Íslandsbanki, which became the only major privately held commercial bank in Iceland, and was publicly listed in 1993. If the Icelandic banking system was, de facto, under the control of the political parties prior to the 1987 crisis, power shifted afterwards to unions and employers' organisations. In general, out of 58.7 per cent of the shares in Íslandsbanki, private pension funds and trade unions owned 32.9 per cent, private employers 17.5 per cent and state funds 8.3 per cent. This meant that Íslandsbanki's backbone was private pension funds and labour movement funds. In 1992, 45 per cent of all the shares that the private pensions fund industry owned were in Islandsbanki. This implies that, despite the inner circle of ASÍ having an active role within the banking industry, Íslandsbanki was well positioned to use the pension funds as a captive pool of money to personally profit, despite the cost to workers.

The existing network of relations between the pension industry, Íslandsbanki and the larger companies clearly opened channels of communications and cooperation among pension funds, industrial companies, insurance companies and other enterprises (Baldvinsdóttir, 1998: 148). This cooperation was sustained both by concentration within the financial market and pension funds, whose number has declined in the last twenty years (Nordic Statistical Committee, 2009)23 and by the concentration of power within ASÍ, where the bargaining process had been getting more and more centralised during the early 1990s. These concentrations had a mutual character. On the one hand, the scale economies required by the financial market's rationality encouraged pension funds amalgamation in order to save in operational costs, diversify the risk and so on. On the other, because pension membership is based on union affiliation, the conglomeration of the labour unions implied a concentration within the pension funds industry. Because many of these same people from the board of ASÍ and SÍ are also on the board of pension 
funds, it follows that decision-making became concentrated in the hands of a few people, who accordingly exerted a large influence on both collective bargaining and on the investment policy of the pension funds. This cooperation means that ASÍ is restricted in what actions it can take to secure a better living standard for its members, since that might affect other interests for which it is responsible, such as in the banking and the pension industries (Baldvinsdóttir, 1998: 157). Two leaders of unions in the public sector expressed their concern over this cooperation between ASÍ and SÍ. They said that whilst ASÍ and SÍ were working in harmony, ASÍ was moving away from other trade union federations, and in many cases working against them (Baldvinsdóttir, 1998: 126).

The problem was that under the new circumstances, the pension fund high returns could come into conflict with labour policies, both at macro and micro levels (Ghilarducci, 1992). First, the introduction of pension funds in company capital ensured that more and more workers adopted the perspective of capital owners, nevertheless strengthening individualisation and solidarity among the working class. Indeed, although their boards consist of an equal representation of workers and employers, the 'deferred wages' are run by the 'pension funds money managers', who are mainly interested in what has been called 'total returns' (Minsky, 1982). This means that trade union leaders remained uninvolved in the investment decisions of the companies, giving the companies' board of directors considerable freedom to use these investments (Baldvinsdóttir, 1998: 266). They could be used to take over or invest in other companies, or, because of the demands of the pension funds for high returns from the companies in which they invested, put increasing pressure on company managements to increase profit and dividends. This meant that workers became 'employees' and 'owners' at the same time, and accordingly, that increasing companys' profitability became their interest.

Second, the new investments opportunities required by the pension funds as well as by other financial institutions transferred considerable parts of economic power from the public sector to the private sector. The strong privatisation programme that got underway in 1991 (OECD, 1999: 82), apart from not being thwarted in any way by ASÍ, laid the base for the reduction of public expenditure, helping private companies to easily take loans from banks (OECD, 1999: 45-47). Pension funds have increasingly been invested in in mutual funds that have played a role in the government's privatisation programme, both as advisors and arrangers (Ministries of Industry and Commerce, 1997). However, not only did the state take on the function of supporting financial expansion, but it also became a source of financial surplus. The social function of the ideology of surplus public budget' has therefore strengthened those political forces that considered the market as the polar star of their actions, making the level of employment ever more dependent on the capitalists' state of confidence, which is often inversely proportion to state activity in the economy (Kalecki, 1943b). ${ }^{24}$

Third, following the liberalisation of market transactions with Iceland's entrance into the EEA in 1994, attention began to be focused on the rapid and ongoing opening and closing opportunities for speculation in one type of assets or another. Pension funds started to be increasingly invested abroad in speculative activities in order to achieve the best return-risk combination available at any time. For a small economy like Iceland, the consequences of worker resource outflow were devastating: if, on the one hand, this huge amount of capital moving out of the country couldn't be used to fund national productive investments, on the other hand, pension funds were heavily affected by turbulence 
in the global market in 2001 and to a greater degree in 2008, causing a massive drop in the wealth of Icelandic workers when the international crisis depreciated many of the assets in which these funds were invested. ${ }^{25}$

Fourth, with the new pension regulation, the list of permissible financial instruments became broad enough to include most types of investment (OECD, 1999: 110), and pension funds were the fundamental actor inflating the Icelandic housing bubble rapidly from the early 2000s up to the 2008 crisis. ${ }^{26}$ Although the rise in housing prices was first and foremost due to the entry of the newly privatised banks into the Icelandic housing mortgage market (Sveinsson, 2011: 68), pension funds played a crucial role by investing in those mortgages' bonds issued by the banks. ${ }^{27}$ When the lender can be divorced from from the innate risk of all loans in such a way, however, there is no incentive to investigate financial security and borrowers' ability to pay. This means that pension funds had no control over which households were issued loans, nor their terms (IFRI). ${ }^{28}$ Because all long-term housing loans were linked to the consumer price index, the collapse of the króna and the explosion of inflation in the first several months of the 2008 crisis increased housing loan debt by nearly 30 per cent across the board in nominal value. As a result, those who had debts (mortgages and consumer debts) in Icelandic króna became the victims of increased inflation associated with the collapse (Ólafsson, 2010: 32).

Last but not least, the flow of pension funds into the international speculative market benefited from high domestic interest rates in spite of helping them to improve their rate of return from domestic financial investment, as well as allowing them to purchase foreign securities relatively more cheaply. This had nevertheless made the expansion of productive investments inside the country more difficult. Actually, the establishment Íslandsbanki has often led the way for the other banks by setting high interest rates, which has been the one of the main factors in helping the pension funds to build up their assets and improve their financial standing (Baldvinsdóttir, 1998: 141). Although the 'social partners' officially continued to be involved in discussions focusing on how to lower inflation, and ASÍ's leadership assured its membership that interest rates would decrease in order to revitalise investments, the interest rates continued move forward. As the trade unions were heavily criticised for having failed to get interest rates down, the government established a wage committee with representatives from ASÍ and SÍ, with the task of monitoring the cost of living and with the aim of working towards lower interest rates. The three trade union officials sitting on this committee, however, were the same directors that sat on the board of Íslandsbanki and on the larger pension funds (Óskarsdóttir, 1997), for which anti-inflationist measures were presumably most appropriate to fill the pension funds and banks' coffers. Alike, the pension funds' massive investments in private mortgage market generated another paradox of the retirement workers' savings: if the interest on mortgage loans is low, although the mortgager (often a worker) will benefit from it, then his pension will likewise be low. If the interest payments are high, although the mortgager-worker will run into difficulties, then his pension will likewise become higher. The result was that right before the bursting of the speculative bubble in October 2008, the real interest rates in Iceland were at 15 per cent, stimulating further financial profitability, carry trade, currency appreciation and a huge level of debt. ${ }^{29}$ The latter dynamic has also been described in detail by Wade and Sigurgeirsdóttir. However, this is only the final part of the story. To stick to this means to fall into a trap of financial determinism, because it overlooks the fact that the pension- 
fund industry was a decisive device that, interlinking the unions, employers and government's actions and embedding industrial relations in a financial economic context, made the social actors fundamental players in restoring capitalistic (financial) accumulation.

\section{The rescuer of last resort}

The perverse consequences of financialisation on the working class have been revealed in their entirety with the explosion of the financial crisis in 2008, which further pushed the subsumption of labour under financial capital. Since the beginning of emergency in October 2008, ASÍ has not offered any noteworthy resistance to the government's determination to shift the crisis onto the workers. ${ }^{30}$ Rather, it followed the dictates of the IMF, which provided a loan of USD $\$ 2.1 \mathrm{bn}$, subject to the running of a 'structural adjustment programme'. Such an amount is approximately equal to the total direct fiscal costs of the financial crisis (about 20 per cent of GDP), which is higher than in any other country except Ireland (OECD, 2011: 20). Even leaving aside the IMF loan's interest, each Icelander is forced to contribute a staggering USD $\$ 8,000$ to bail out those financial institutions that helped cause the financial meltdown. In a document released in the wake of the collapse of the banking system, the ASÍ congress claimed, 'Assistance from the IMF is a key step towards boosting confidence and achieving these objectives [currency appreciation as a prerequisite of lower interest rates]' (ASÍ, 2008). The desire to regain 'financial stability' in Iceland was finally formalised at the end of June 2009 through a neo-corporatist agreement, officially named the 'Stability Pact', between the left-green/ social-democratic government, trade unions and employers' organisations, which satisfied the whole set of IMF's policies. The goals of the Pact are as follows. First, the restoration of a 'functioning and viable banking system' by a massive operation of recapitalisation by means of public resources, with a view to the next privatisation in the future. Second, 'stabilisation of the currency' in order to combat the threat of inflation and to stem capital outflow by increasing the interest rates which have further strangled investments. Third, 'consolidation of the fiscal position', which has dramatically worsened as a consequence of the injection of public funds in favour of the banks and the repayments of the debts to the IMF - by increasing income taxes and implementing fiscal restraints, i.e. cuts in social spending, tighter means testing for social benefits, reductions in the wage bills, and significant scaling back of investment spending (IMF, 2009a).

Although the bail-out of the capitalist class at the expense of the working class represents the usual way in which capitalism has historically tried to resolve its contradictions (crisis), the unprecedented qualitative datum consists of pension fund exploitation to finance the IMF's rescue package - first and foremost the recapitalisation of the three new banks, and the funding of the fiscal austerity that it implies. No matter that such funds have incurred significant losses as a result of the bankruptcy of the private banking system and the national and international stock market collapse; ${ }^{31}$ they nevertheless seem to be the only entity in Iceland with any liquidity today, which needs to be put to work. In agreement with the government and the Central Bank, and after measures to restrict currency outflows temporarily in order to prevent capital outflow were introduced by those bodies in October 2008, the trade unions and employer confederation decided to transfer a considerable amount of the pension fund liquid foreign assets into Iceland- which as a result went down from 26 to 21 per cent of their entire portfolio 


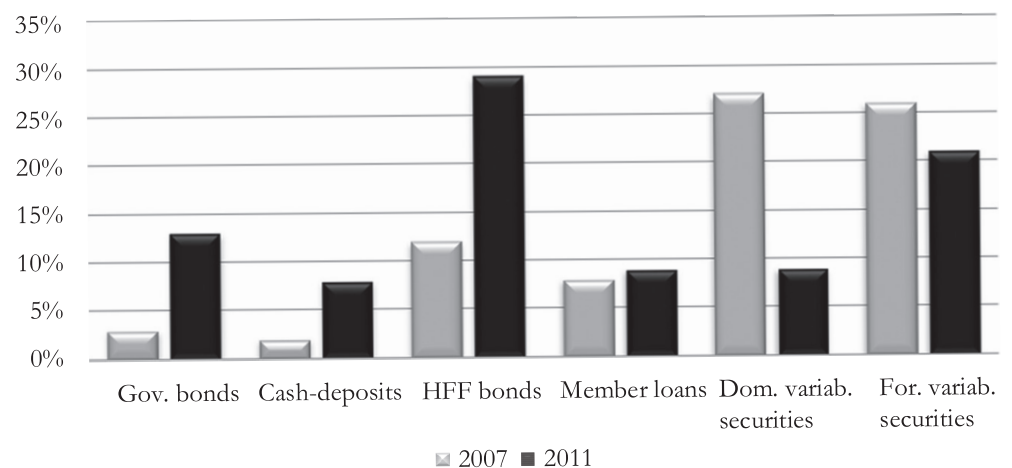

Figure 8. Pension fund's assets (2007-2011)

Source. Author's elaboration from Central Bank of Iceland data.

(Figure 8). This was an attempt to strengthen the króna (Magnússon, 2008), to sustain the Icelandic stock market, and, according to the labour leadership claims, to increase productive capacity by means of public investments.

Concerning this last point, the same Stability Pact promised that 'concerted effort will be made to move forward on plans for other major industrial investment' such as hospitals, tunnels, schools and highways in order to increase income levels and as a result, employment in the interests of their owners, i.e. the workers. Predictably, due to the embeddedness of the pension funds in the financial market mechanism, the ideological attitude of the social partners they are managed by, the difficult state of the government's finances, and the constraints laid down by the IMF plan, these prospects have been revealed to be deceitful. To date, no public social investment from pension funds has been made, whereas pension-fund holdings in national companies are at an all-time low (Anderson, 2009a; Anderson, 2009b; News Frettir, 2009a; News Frettir, 2009b; Agnarsson, 2010; Coats, 2011a; Coats, 2011b). The reality is that, with no real corporate bond or equity market to invest in due to the dearth of domestic investment opportunities with an acceptable risk-return balance (Sighvatsson, 2010), along with the capital restriction that de facto forbade the making of new investments in foreign currency-denominated assets, the occupational pension funds had few options apart from buying government-guaranteed paper and bank deposits (Roerhrbein, 2010, IMF, 2011: 5 ) in order to lower the financial pressures of the country and to buy back some of their long-term debt to the Icelandic banks (Buiter and Sibert, 2008: 10-22). Although three rating agencies - Moody's Investors Service, Fitch Ratings, and Standard \& Poor's assigned a negative sovereign credit rating to the Republic of Iceland, Icelandic pension funds have increased by more than tenfold their purchase of securities issued by the Central Government, from almost ISK21 million in November 2007 to more than ISK272 million in May 2012. Put differently, by purchasing tradable but very risky government bonds, the deferred workers' salary is injected into the three banks, Glitnir, Kaupthing and Landsbanki, all nationalised in 2008, but which have since been largely re-privatised. ${ }^{32}$ This has limited the funding pressures on the domestic financial market. 
The most conflicting operation in this process was the so-called 'Avens deal', after which the HFF bonds share in the pension funds' portfolio increased from 12 to 29 per cent (Figure 8). HFF is a wholly owned state provider for mortgage loans which aims to provide access to housing for low-income households, accounting for 64 per cent of Iceland's ISK1.23 trillion in outstanding mortgage debt at the end of June $2010 .{ }^{33}$ Despite the fact that ratings agencies were giving a negative outlook on such bonds, in May 2010, 26 pension funds agreed to liquidate foreign assets to pay a price of $€ 549 \mathrm{~m}$ to purchase the far more risky HFF bonds worth ISK90bn, owned by the Treasury. The aim was to help boost liquidity into the economy, by increasing the Central Bank of Iceland's foreign exchange reserves as well as to pay all of the Treasury's debt until 2015, by providing it with low-cost, long-term funding (Central Bank of Iceland, 2011: 9, 11). Már Guðmundsson, governor of the Central Bank of Iceland, best described the impact of 'Avens deal': 'This agreement paves the way for the removal of capital controls while highlighting the enormous advantage that lies in Iceland's having such strong pension funds. With their participation, our pension funds have put their shoulder to the wheel of the economic recovery' (Central Bank of Iceland, 2010).

This transaction could give rise to (and in some cases it has already given rise to) very negative consequences for the rightful owners of the pension funds, namely the workers. First, the extremely low interest rates at which these schemes have lent money to the Treasury ${ }^{34}$ mean that they will ensure virtually no returns on workers' pensions. Second, the slump by more than 20 percent in real disposable incomes of Icelandic households in a context in which their debt reached about 220 percent of disposable income, higher than that of the USA (IMF, 2008: 9), has further weighted the household debt burden, making 40 percent of homeowners 'technically insolvent' (Valdimarsson, 2010a). This means that the pension funds invested in HFF bonds, despite the risk of default of this institution that could occur, would burn substantial amounts of workers' resources. Third, and directly connected to the previous point, due to the fact that pension funds are currently Iceland's main mortgage lenders, this has rendered pension funds a kind of de facto debt collectors. This explains why pension funds have fiercely opposed the proposal advanced by some members of the government and the committees of the families to write-off bad loans with the purpose of helping those households increasingly strangled by mortgage debt. Precisely because 'this measure would mean that members will see their pensions cut' (Valdimarsson, 2010b), as the managing director of the Icelandic Pension Funds Association clearly admitted.

Finally, with capital controls having temporarily stopped further foreign investments, the pension funds played an important role in the process of the 'consolidation of the fiscal position', by financing the large fiscal deficit (Guðmundsson, 2010:3) due to the nationalisation of the failed banking system. As the chief of the IMF Icelandic mission sincerely pointed out, external debt as well as public debt are sustainable thanks to pension funds. Although acting casually, he declared that 'the public and external debt stock is expected to decline [because] Iceland does not face the same fiscal problems that other countries have thanks to its funded pension system [and that] Iceland has significant foreign assets, including those held by the country's fully-funded pension system' (IMF, 2009b). The meaning of these words is quite clear. Or if it isn't, then the task of the workers' pensions is better specified in the next IMF Report: 'Iceland's funded pension system is a key comfort when considering medium-term fiscal sustainability. Iceland's funded pension 
system has assets, based on end-2008 data, in excess of 100 per cent of GDP .... The fully-funded pension schemes in Iceland imply that there are no hidden fiscal adjustment needs' (IMF, 2009c).

$A S I^{\prime}$ 's support was crucial for the implementation of the fiscal consolidation as provided for in the IMF's structural adjustment plan. Although, since the end of 2007, Iceland has experienced the highest unemployment increase and the heaviest fall in real wages among OECD countries, the centre-left coalition was very fast and successful in putting IMF prescriptions into practice due to the social peace guaranteed by the Federation of Labour: 'The government was able to agree on a fiscal package with its social partners, and good progress has been made on the immensely complicated task of restructuring Iceland's failed banks .... The government has implemented spending cuts and revenue-raising measures ... to keep the ... deficit contained, and has put together a medium-term adjustment plan that has the support of labour unions and other social partners' (IMF, 2009b).

\section{Summary and conclusions}

In this paper, I have explored the decisive role of the pension funds in the restructuring of the Icelandic economy, arguing that, through their involvement in the pension funds industry, the labour unions greatly contributed to laying the foundations of economic financialisation. This has involved a detailed study of the co-evolution of industrial relations with the ongoing process of economic financialisation, where they adjusted to one another until a viable institutional configuration emerged (Crouch et al., 2005: 367). First, I examined how the export-led growth regime of accumulation's structural crisis produced an explosion of inflation and labour conflictuality in the late-1980s. Yet the goals of matching satisfactory profitability in the leading sector of the economy, i.e. fisheries, with the restraint of inflation seemed to have become incompatible, due to the low productivity of Icelandic industries combined with industrial relations' inability to guarantee cooperation between labour and capital, specific to this regime. Second, I retraced the way the concentration of power within the Icelandic Federation of Labour (ASI) and the increasing centralisation of the bargaining system enabled lower inflation and stabilisation of the currency. Although there was no economic determination of institutions, but rather contingency and scope for strategic choice (Boyer, 1988), this led to a massive redistribution of income in favour of profits. However, real economic activity held steady due to the endless increase in interest rates that, although strangling new productive investments, provided many profitable opportunities in the financial sector by absorbing enormous masses of speculative capital from the rest of the world. In these circumstances, the socioeconomic stability provided by the labour organisations was the vital element on which the new financial regime of accumulation was built. It enhanced the national economic 'credibility' that, combined with the liberalisation of the financial market, helped the internal market to attract foreign speculators as well as gaining access to loans from international markets (Screpanti, 2001).

Third, I argued that the Icelandic unions' consensus concerning the 'stabilisation programme' implemented by the neoliberal coalitions relies on their embeddedness into the financial structures of the national economy through financial institutions, namely occupational pension funds. Through their establishment, a new 'actor-network' has 
been constructed by the unions and employers who managed them, along with the financial sector. Thus, new power relations emerged which appear to have united two essentially divided groups with diametrically opposed interests. Since then, as Baldvinsdóttir (1998) has pointed out, 'the "interests" of the trade unions have become so tightly entwined with employers' interests, mainly through the pension industry, that they cannot be separated'. In other words, the leaders of ASÍ have, through the pension industry, become locked into a network of relations which have had 'unintended' consequences for the ordinary members of ASÍ. Once traditional channels of investments exhausted their profitability opportunities, these cooperations and linkages sped up the creation of those structural conditions - i.e. low inflation (or wage repression) and stable currency exchange - a preparation to the relaxation of financial restrictions, allowing these funds to find new channels to invest in. ${ }^{35}$ As one of the biggest savings institutions in the country, the need for assets of the occupational pension funds was one the main drivers behind the reversal of the causal link between the real and the financial economy (Engelen, 2003: 1367).

Fourth, I analysed how the involvement of Icelandic trade unions in the financial mechanisms through the pension industry generated a degree of identification with pro-market governmental policy on the part of union leaders, encouraging them to tailor their own strategies accordingly. This was particularly evident in the aftermath of the banking crisis that hit the country in October 2008, where the workers' resources were used to save and restore the same financial environment that has ultimately conducted Iceland first towards stagnation, then towards financialisation, and lastly towards a collapse. Contrary to what is going on in Greece, Ireland, and many other countries, where the national trade unions are manifesting their disagreement with the structural adjustment packages imposed by the IMF, the Icelandic Federation of Labour was committed to immediately starting a collaborative, consensus-building process that would be required for the implementation of the IMF macroeconomic programme, with all the well-known consequences it implies. ${ }^{36}$ As 'institutions of money', whose main goal is profit-seeking activity, Icelandic unions are still buried in a vicious circle: any conflictual actions could destabilise the economy and allow capital-holders to 'punish' policies that fail to match the criteria of rectitude embraced in financial markets (Hyman, 1999: 92).

Approaching the problem from a Polanyian-Regulationist perspective, the Icelandic case masterfully shows how the instauration of a financial expansion was not a natural development: it was created by and embedded within politics and society. To narrow the sphere of the economic genus specifically to market phenomena is to eliminate the greatest part of man's history from the scene (Polanyi, 1977: 6). Thus neglecting the significance of broader structural determinants, it is then only too easy to attribute unions' strategies to the personal characteristics of members or leaders (Hyman, 1975: 69). Through their connection with the pension funds industry, Icelandic trade unions were structurally coupled to the financial mechanism: they were 'embedded' within it. This means that economic liberalisation did not replace the organisations with the 'market'; that is, it did not push towards the disorganisation of labour relations, as the prevailing governance mechanism. Nevertheless, the Icelandic case highlights the fact that the pension funds high returns (market) can conflict with labour policies (society), both at macro and micro level. The intensification of pressure specifically for short-term yields 
has diverted the pension funds in speculative circuits that are ever more risky, creating the illusion of an autonomous and automatic prosperity. In such a way, Icelandic employees achieved improvements in real wages, pension returns, and social benefits since the late1990s. The economic crisis in 2008, however, revealed that the complementarities between financial markets, pension funds, workers' welfare and neoliberal political economy were sustained only by means of an extreme indebtedness and risky investments strategies through which the same workers were sucked into a vortex of speculative economic growth. The study of the interrelationship between industrial relations and financial markets by focusing on their link, i.e., the occupational pension funds, is therefore a powerful tool able to contradict the hypothesis of financial determinism. To widen the scope of the enquiry to other national contexts in which a private financial institution has gradually emerged as a mediator of workers' need for pensions, means nevertheless to change the perspective from which the role of labour organisations in affecting national economic policy is usually analysed. This means that the worker organisations involved in pension funds management should not be considered as merely passive players during the phase of economic financialisation, but rather as fundamental players in restoring capitalist accumulation.

\section{Acknowledgement}

I am indebted to Robin Chang, Leo Panitch, Leonardo Bargigli, Guglielmo Carchedi and Íris Stefánsdóttir for the discussions, comments and ideas that made this article possible. Any errors arising are my own.

\section{Notes}

1. The potential replacement ratio (at normal retirement age) of the public pension as a percentage of final earnings is less than 10 per cent in Iceland, which is four to five times less than in other Nordic countries. Iceland currently spends only 2 per cent of GDP on basic and supplementary state pensions.

2. Voluntary pension schemes have not been of great significance in Iceland.

3. The main implication of this was that only members of a pension fund that had invested in the house founding system could get mortgages, and then only if their premium had been paid to the pension fund (Baldvinsdóttir, 1998: 139-40). Since this is the only institution in Iceland from which a mortgage loan is available, this led to an increase in pension funds memberships (SAL-fréttir, 1992).

4. What tends to happen is that the contribution rate remains relatively stable, but the benefits rates at retirement change from time to time to maintain the balance of the fund, with the consent of the members (OECD, 1999: 107). For a long time, the Icelandic pension system in the private sector was purely in the DC model. From their establishment up to 1997, no law had been passed protecting a member's right to even a minimum pension. The Occupational Pensions Act passed in 1997 tried to reduce this imbalance against workers by targeting a given replacement rate for the occupational plans target, and by providing minimum benefit guarantees, equal to 56 per cent of monthly pay, if contributions had been paid for 40 years (OECD, 2008: 53-54).

5. The predominance of the fishing industry in exports is an important structural feature of the Icelandic economy. Marine products contributed more than 80 per cent of total export earnings until the late-1980s.

6. From the Second World War until the early 1970s, the króna was pegged against or at least managed with respect to the currency of some trading partner country or a basket 
of currencies, but with varying degrees of adjustability and commitment (Guðmundsson, 2002: 15). After the collapse of Bretton-Woods, the Icelandic exchange rate regime became increasingly flexible, and could be characterised as 'managed floating'.

7. For most of the nation's history as a republic, Iceland had the highest labour force participation rate and one of the lowest unemployment rates in the OECD (OECD, 1997: 103). During the period under consideration, the unemployment rate fluctuated between 0.3 and 1.3 per cent.

8. Long-term foreign debt as a percentage of GNP passed from 31 in 1981 to 56 per cent in 1985. In general, debt in foreign currencies increases the production costs of local firms if the national currency is devalued.

9. The first coalition was formed by the right-wing Independent Party (IP) with the reformist Social Democratic Party (SDP) and the agrarian Progressive Party (PP). The second one was formed by the SDP, the PP and the left People's Alliance (PA).

10. Using the ILO report's words (1989), the government 'clearly restricted the right of employees and worker organisations to engage in free collective bargaining during the term of the legislation. ... This was the ninth instance of such intervention in ten years.'

11. ASI's leaders argued that the workers had to cooperate with employers in an effort to accept wage restraints for the duration of the recession, in the hope that such cooperation could help to restructure firms.

12. Until the period of exchange-rate stability beginning in June 1993, the longest period of exchange-rate stability of the króna since the early 1970s was from December 1989 to November 1992. At the beginning of 1992, the previous trade-weighted basket was replaced with a new one composed of the ECU with a weight of 76 per cent, the US dollar with a weight of 18 per cent, and the Japanese yen with a weight of 6 per cent. Iceland adopted an inflation target and a floating exchange rate in 2001.

13. Between 1995 and 2006, the governments slashed corporate tax rate almost in half, from 33 to 18 per cent.

14. In the 1990-2006 period, the gross value added in the fishing sector increased by 34 per cent in Denmark, 4 in Finland, 20.6 in Norway and 14.3 per cent in Sweden. In contrast, it decreased by 1.5 per cent in Iceland.

15. About 90 per cent of Icelandic firms can be classified as non-efficient in the process of transforming labour, capital stock and $\mathrm{R} \& \mathrm{D}$ efforts into output in terms of innovations, productivity and growth (Oh et al., 2009: 5).

16. Borrowing by banks in foreign currencies was not only used to finance their own investments, but also to provide capital to Icelandic companies for expansion, as well as to families for household consumption. The result was that the indebtedness of Icelandic corporations went from a situation in which they were relatively debt free in the early 1990 s, to one in which their debts were equal to 277 per cent of their GDP in 2006. And if at the outset of the 1980s household debt was around 26 per cent of disposable income and 17 per cent of GDP, by the end of 2006, household indebtedness had reached 116 per cent of GDP and 216 per cent of disposable income. At the same time, due to the small size of the national economy, many Icelandic businesses outgrew national borders by setting up branches and acquiring other financial institutions in neighbouring countries. Icelandic foreign direct investments, which historically have largely been made up of seafood firms, were now replaced by the three main Icelandic banks, real estate, and business companies which have set up branches abroad in several countries, acquiring foreign financial firms. Between 1998 and 2005, FDI stock in financial activities went from USD $\$ 1 \mathrm{~m}$ to more than USD \$5300m (Hermannsdóttir et al., 2007).

17. Quotas could be separated from vessels and transferred as an independent commodity to other vessel owners. 
18. With the new system, the winners were the big quota owners, while the losers were the fishermen who have been thrown into a market in which only the lowest bidder gets a chance to catch fish (Eypórsson, 1996: 281).

19. According to ASÍ, by making the fisheries more efficient, the system would boost the national economy and provide higher and more secure income for fishermen, whereas the bargaining position of fishing crews would improve, resulting in higher wages (Árnason, 1992).

20. In a context in which strikes are restricted when a collective agreement is being signed, the extension of the validity of contracts made it more difficult to call for strikes. While between 1976 and 1989 twelve agreements were reached whose duration was 13.1 months on average, from 1990 to 2008, only six agreements were signed, with durations longer than 36 months on average.

21. Ezio Tarantelli (1978) clearly described monetarism' effects on the working class: 'The dominant elite structures the labour force. The subject of the history is not anymore the labour movement that continually is trying to set out to conquer new rules, but rather the ideology of the dominant bloc from whose "health function" is derived the cooptation action of the union in order to obtain its consensus .... At institutional level, [this] paradigm laid the ideological base of the income policies, productivity agreements, consultation, etc.'

22. Since the mid-1980s, ASÍ's central committee has collectively been in the hands of the People's Alliance, the IP and the SDP. However, the ASÍ leadership was characterised by its cooperation with the IP and the SDP against the PA.

23. The number of funds has been falling in recent years due to mergers aimed at improving efficiency. They numbered around 90 at the beginning of the 1980s. At the end of 2007, they had fallen to 31 . The ten largest pension funds held about 80 per cent of the net assets of all pension funds in 2007, and the two largest funds accounted for 35 per cent.

24. Since the late-1990s, the general government financial balance has more often been in surplus than in deficit. Gross public debt declined from almost 60 per cent of GDP in 1996 to 27 per cent in 2005, while the general government financial balance in ratio to GDP passed from -4.7 per cent in 1994 to +6.3 per cent in 2006 .

25. Although households' assets reached more than 400 per cent of GDP in 2007, they were evenly split between real assets and financial assets -70 per cent of which were subject either to real estate market risk or equity market risk, with the latter risk mainly being indirect through pension funds (OECD, 2009: 30).

26. In the Reykjavik area, housing prices reached their apex in 2007, at 126 per cent higher in real terms than in 1996 (Sveinsson, 2011: 63).

27. By the end of 2007, roughly a quarter of the ISK1650bn (Icelandic króna) in assets controlled by pensions were invested in mortgages indexed to inflation. In the same year, pension funds held 43 per cent of the stock of housing bonds.

28. The deregulation in the sector carried out in 1997 potentially contained this risk.

29. In 2007, the nominal short-term interest differential with the USA, the Euro area and Japan was 9.3 per cent, 11.1 per cent and 14.5 per cent, respectively. This attracted carry traders speculating against 'uncovered interest parity'.

30. The last collective agreement signed between ASÍ and SÍ at the beginning of May 2011, valid for a record length of 3 years, went in the same direction. According to this contract, the general wage would rise by 4.25 per cent the first year, by 3.50 the second one, and by 3.25 per cent the last year. But already in the period June-October 2011, the average inflation rate exceeded 5 per cent (Statistics Iceland). What this means is that the real wages of Icelandic workers are still under attack. However, since in Iceland the right to strike is restricted when a collective agreement is being signed, ASÍ has guaranteed, de facto, a prolonged period of social peace. The latter is necessary to keep those 'wage deflation policies' required to adjust the fiscal deficit for the next several years. 
31. From January to October 2008, net assets for pension payments decreased by 19.13 per cent in real terms.

32. Once nationalised, these banks were named respectively Islandsbanki, Arion and New Landsbanki. Currently, the first is 95 per cent owned by ISB Holding, a company controlled by the old bank's creditors. The government owns the rest. The second is 87 per cent owned by creditors, with the government holding 13 per cent. The last bank was given more time to work out a new ownership structure. New Landsbanki is 81.3 per cent owned by Icelandic State Financial Investments, a state holding company (Henning, 2011).

33. HFF was not directly funded by the state, but was financed through returns on its own, through issuing HFF bonds which were listed on the Icelandic Stock Exchange and through service fees from customers.

34. According to the agreement, the interest rate applied is 0.75 per cent for the next 15 years.

35. Hrafn Magnússon, who has headed the pension funds association for 36 of the industry's 41 years' existence, sincerely replied to the question as to whether the pension funds were hubristic before the crisis. He said: 'Yes, I think that they [the pension funds] behaved like everyone in Iceland ... Everybody thought we were so clever and that we could buy almost anything. And the members were very happy to take the good returns although they were angry when, after the crisis, their pension decreased' (Coats, 2011c).

36. In the aftermath of the financial collapse, the unemployment rate skyrocketed to more than 9 per cent from less than 1 per cent the previous year. The employment rate decreased by more than 5 points, and real wages fell by 12.2 per cent. In the meantime, Icelandic workers were hit by a vast programme of public spending cutbacks as well as by the increasing of indirect taxes. On the political horizon, Iceland was experiencing a vibrant period of social unrest and widespread political protests that resulted in the resignation of the government led by the Independent Party. Despite this explosive mix, the Icelandic labour market continued to be one of the quietest among OECD countries. In 2009, not a single working day was lost due to labour disputes (Statistics Iceland, 2011: 101), while in 2010 only public-sector workers went on strikes, mainly pilots and mechanics employed by the flag carrier, fire-fighters and ambulance drivers.

\section{References}

Aðalsteinsson GD (2007) Can Strike Theories Introduced in the 1960s and 1970s Explain Different Levels of Strike Trends in the Nordic Countries in the 1980s and 1990s? Reykjavík: Institute of Business Research, University of Iceland. Online at <www.ibr.hi.is >.

Agnarsson S (2010) Labour Market Development and Policy in Iceland, European Employment Observatory. Online at <www.eu-employment-observatory.net>.

Agnarsson S, Arnason R (2003) The Role of the Fishing Industry in the Icelandic Economy. A historical examination. Reykjavík: Institute of Economic Studies, University of Iceland. Online at $<$ https://ioes.hi.is $>$.

Agnarsson S, Hall A, Herbertsson TT, Ingólfsson S, Magnússon G, Zoega G (1999) Emu and the Icelandic labour market. Reykjavík: Central Bank of Iceland, Economic department. Online at <www.sedlabanki.is $>$.

Allen F, Bartiloro L, Kowalewski O (2006) The Financial System of the EU 25, in Liebscher K, Christl J, Mooslechner P, Grunwald DR (eds.) Financial Development, Integration and Stability: Evidence from Central, Eastern and South-Eastern Europe. Cheltenham: Edward Elgar.

Amable B, Ekkehard E, Palombarini S (2005) How do financial markets affect industrial relations: An institutional complementary. Approach, Socio-Economic Review 3(2), pp. 311-330.

Andersen S, Guðmundsson M (1998) Inflation and Disinflation in Iceland. Reykjavík: Central Bank of Iceland, Economic department. Online at <www.sedlabanki.is >. 
Anderson S (2009a) Icelandic Pension Fund Venture Stalls. Financial Times Mandate, December.

Anderson S (2009b) Icelandic Funds Team up in Private Equity Venture. Financial Times Mandate, 16 February.

Árnason R (1992) Fiskveiðiarðurinn og skipting hans. In Pálsson G, Árnason R, Jónsson O (eds.) Stjórn fiskveiða og skipting fiskveiðiarðins. Reykjavík: Sjávarútvegsstofnun og Háskólatúgáfan.

Baccaro L, Howell C (2011) A common neoliberal trajectory: The transformation of industrial relations in advanced capitalism, Politics \& Society 39(4), pp. 521-563.

Baldvinsdóttir D (1998) Networks of financial power in Iceland: The labour movement paradox. Ph.D. thesis, Department of Behaviour in Organizations, Lancaster University.

Belfrage C, Ryner M (2009) From pension fund socialism to neo-liberalism: The 'renegotiation' of the Swedish social settlement, Politics and Society 37(2), pp. 257-287.

Bellofiore R, Halevi J (2008) A critique of post-Keynesian economics applied to the political economy of the Eurozone. Paper presented at the 10th anniversary conference of the association for heterodox economics, Cambridge.

Benediktsdóttir S, Danílsson J, Zoega G (2011) Lessons from a collapse of a financial system, Economic Policy 26(66), pp. 183-235.

Benediktsson K, Karlsdóttir A (2011) Iceland: crisis and regional development - Thanks for all the fish?,European Urban and Regional Studies 18(2), pp. 228-235.

Boyer R (ed.) (1988) The Search for Labour Market Flexibility. Oxford: Clarendon Press.

Boyer R (1996) Changing Status of Industrial Relations in a More Interdependent World, Cepremap Working Papers.

Buiter WH, Slbert A (2008) The Icelandic Banking Crisis and What to Do About It: The Lender of Last Resort Theory of Optimal Currency Areas. Centre for Economic Policy Research, Policy Insight no. 26. Online at < www.cepr.org >.

Carchedi G (2001) For another Europe. A class analysis of European economic integration. London: Verso.

Carchedi G (2008) Logic and dialectics in social science, part I: Dialectics, social phenomena and non-equilibrium. Critical Sociology 34(4), pp. 495-523.

Carey D (2009) Iceland: The Financial and Economic Crisis. OECD Economics Department, Working Paper no. 725. Paris: OECD Publishing. Online at <http://dx.doi.org>.

Central Bank of Iceland (2010) Pension Funds Purchase Treasury's HFF Bonds to Strengthen FX Reserves, no. 10, 31 May. Online at <www.sedlabanki.is>.

Central Bank of Iceland (2011) Annual report 2010, Reykjavík.

Coats G (2011a) Iceland's Parliament to Probe Pension Funds' Role in Crisis, Nordic region. Pensions and investment news, 10 February. Online at <www.nrpn-online.com>.

Coats G (2011b) Haukur Hafsteinsson, Managing Director, Lifeyrissjóður starfsmanna rikisins, Nordic region. Pensions and investment news, 20 June. Online at <www.nrpn-online.com>.

Coats G (2011c) Icelandic Pensions Bid Farewell to Industry Veteran Magnússon, Nordic region. Pensions and investment news, 20 June. Online at <www.nrpn-online.com>.

Cowan RS (1987) The consumption junction: A proposal for research strategies in the sociology of technology. In Wiebe EB, Hughes TP, Pinch T (eds.) The Social Construction of Technological Systems. Cambridge: MIT Press.

Crotty J (2008) Structural Causes of the Global Financial Crisis. A Critical Assessment of the 'New Financial Architecture, PERI working paper series, no. 180. Online at <www.peri.umass.edu>.

Crouch C, Streeck W, Boyer R, Amable B, Hall PA, Jackson G (eds.) (2005) Dialogue on 'institutional complementarity and political economy'. Socio-Economic Review 3(2), pp. 359-382.

Daniels G, McIlroy J (2009) Trade Unions in a Neoliberal World. London: Routledge.

Daníelsson Á (2008) The Great Moderation, Icelandic style. Reykjavík: Central Bank of Iceland, Economic department. Online at <www.sedlabanki.is $>$. 
Daníelsson J, Zoega G (2009) The Collapse of a Country. Reykjavík: Institute of Economic Studies, University of Iceland. Online at <www.hi.is $>$.

Dølvik JE (2008) The Negotiated Nordic Labour Markets: From Bust to Boom Background, paper for the conference 'The Nordic Models: Solutions to Continental Europe's Problems? Center for European Studies, Harvard University. Online at <www.ces.fas.harvard.edu>.

Duménil G, Lévy D (2004) The neoliberal compromise, New Left Review 30, pp.105-133.

Eðvarðsson IR (2003) Labour Market Performance in Iceland, Working papers series, Faculty of Business Administration and Management University of Akureyri, Iceland.

Eggertsson T, Herbertsson, TP (2005) Evolution of Financial Institutions: Iceland's Path from Repression to Eruption. Reykjavík: Institute of Economic Studies, University of Iceland. Online at <https://ioes.hi.is>.

Engelen E (2003) The logic of funding European pension restructuring and the dangers of financialization, Environment and Planning 35(8), pp. 1357-1372.

Engels F (1972 [1895]) Letter to J. Bloch. Moscow: Progress.

Evans T (2009) Money and finance today, in Grahl L (ed.) Global Finance and Social Europe. Cheltenham: Edward Elgar.

Eythórsson E (2000) A decade of ITQ-management in Icelandic fisheries: Consolidation without consensus, Marine Policy 24(6), pp. 483-492.

Financial Supervisory Authority (2009) Pension Funds in Iceland. Annual Accounts for 2008 and Other Information, Reykjavík. Online at <http://esb.utn.is>.

Fine B (2007) Rethinking critical realism: Labour markets or capitalism? Capital \& Class 31, pp. 125-129.

Fine B (2009) Financialisation and Social Policy, paper presented at the UNRISD conference, 12-13 November, Geneva. Online at <http://eprints.soas.ac.uk>.

Ghilarducci T (1992) Labor's Capital: The Economics and Politics of Private Pension. Cambridge, MA: MIT Press.

Grahl J (2010) Global Finance and Social Europe. Cheltenham: Edward Elgar.

Guðmundsson M (2001) The Icelandic Pension System. Reykjavik: National Association of Pension Funds. Online at <www.ll.is $>$.

Guðmundsson M (2002) Exchange Rate Arrangements of Microstates: General Assessment and the Case of Iceland, Paper prepared for the conference 'Iceland and the world economy: Lessons for small countries in the era of globalization', Harvard University. Online at <www.cid. harvard.edu>.

Guðmundsson M (2010) The Icelandic Pension System and the Financial Crisis, Speech at the opening dinner of the European Pension Convention 2010, Reykjavík, 2 May. Online at <www. bis.org>.

Guðmundsson M, Kristinsson YÖ (1997) Monetary Policy in Iceland during the Nineties, Paper presented at the BIS meeting on Monetary Policy in the Nordic Area: Experiences since 1992, Bank of International Settlement. Online at <www.bis.org>.

Guðmundsson M, Pétursson TG, Sighvatsson A (2000) Optimal exchange policy: The case of Iceland, in Guðmundsson M, Herbertsson TT, Zoëga G (eds.) Macroeconomic Policy: Iceland in an era of Global Integration. Reykjavík: University of Iceland Press.

Gylfason T (1990) Exchange rate policy, inflation, and unemployment: The Nordic EFTA countries, in Argy V, De Grauwe P (eds.) Choosing an Exchange Rate Regime. The Challenge for Smaller Industrial Countries. Washington DC: IMF.

Henning E (2011) Iceland aims for Bank Consolidation. Wall Street Journal, 19 January. Online at $<$ http://online.wsj.com>.

Herbertsson TT (2005) The Icelandic Pension System in 2005, Paper prepared for Icelandic Pension Funds Association (IPFA) Reykjavik. Online at <www.ll.is $>$. 
Hermannsdottir A, Berglind TA, Ólafsson S (2007) Overview of Foreign Investment from Iceland, 1998 to 2005. Reykjavík: Institute of Business Research, University of Iceland.

Hollingsworth JR, Boyer R (1997) Contemporary Capitalism: The Embeddedness of Institutions. Cambridge: Cambridge University Press.

Huffschmid J (2009) Protection of the elderly against the risks of capital markets: The advantages of public PAYGO pension systems, in Grahl L (ed.) Global Finance and Social Europe. Cheltenham: Edward Elgar.

Hyman R (1975) Industrial Relations: A Marxist Introduction. London: Macmillian.

Hyman R (2007) How can trade unions act strategically? Transfer 13(2), pp. 193-210.

Icelandic Federation of Labour (2008) Economic Outlook for Iceland 2008-2010. Reykjavík: Economic department, Statistics Iceland database.

Statistics Iceland (2011) Statistical Yearbook of Iceland 2011, Reykjavík.

IFRI, Pension Funds and Mortgages. Online at <www.ifri.is >.

ILO (1989) Complaint Against the Government of Iceland Presented by the Icelandic Federation of Labour, Report no. 262, case(s) no(s). 1458.

IMF (2008) Iceland: Request for Stand-By Arrangement, IMF Country Report no. 08/362. Online at $<$ www.imf.org $>$.

IMF (2009a) Iceland: Letter of Intent, Memorandum of Economic and Financial Policies, and Technical Memorandum of Understanding, Reykjavik, October 20. Online at <www.imf.org >.

IMF (2009b) Iceland: Quiet Progress on Key Reforms. Online at <www.imf.org>.

IMF (2009c) Iceland: Staff report for first review under stand-by arrangement and requests for extension of the arrangement, waivers of nonobservance of performance criteria, and rephrasing of access. IMF Country Report no. 09/306. Online at <www.imf.org>.

IMF (2011) Iceland: Fifth review under the stand-by arrangement, and request for modification of performance criteria and rephasing of access, IMF Country Report no. 11/125. Online at $<$ www.imf.org $>$.

Iversen TP (1996) Flexibility, and the breakdown of centralized wage bargaining: Denmark and Sweden in comparative perspective, Comparative Politics 28(4).

Jessop B, Sum NL (2006) Beyond the Regulation Approach: Putting Capitalist Economies in Their Place. Cheltenham: Edward Elgar.

Jónsson BB (1999) Financial Indexation and Interest Rate Policy in Iceland, Central Bank of Iceland, Economic department. Online at <http://sedlabanki.is $>$.

Jónsson G (2004) The transformation of the Icelandic economy: Industrialization and economic growth, 1870-1950, in Heikkinen S, Zanden J (eds.) Exploring Economic Growth: Essays in Measurement and Analysis New York: Academic Press.

Jónsson Í (1991) Hegemonic politics and accumulation strategies in Iceland 1944-1990, Ph.D. thesis, University of Sussex.

Jónsson Í (1995) West-Nordic Countries in Crisis. Copenhagen: New Social Science Monographs.

Júlíusdóttir L (2002) Icelandic labour law. In Stability and Change in Nordic Labour Law. Stockholm Institute for Scandinavian law.

Kalecki M (1943a) Political aspects of full employment, Political Quarterly 14(4), pp. 322-31.

Kalecki M (1943b) The Last Phase in the Transformation of Capitalism. New York: Monthly Review Press.

Keynes JM (2000 [1923]) Tract on Monetary Reform. Amherst, NY: Prometheus Books.

Kjartansson, H.S. (1992) Iceland, in Campbell J (ed.) European Labor Unions. Westport, CT: Greenwood Press.

Knutsson O, Gestsson H (2006) The Icelandic Fishing Industry: A comprehensive Overview Until the End of 2001. Akureyri, Iceland: University of Akureyri. Online at <http://skemman.is>.

Kochan TA, McKersie RB, Cappelli P (1984) Strategic choice and industrial relations theory, Industrial Relations 23(1), pp. 16-39. 
Korpi W, Shalev M (1979) Strikes, industrial relations and class conflict in capitalist, British Journal of Sociology 30(2), pp. 164-187.

Krippner G (2004) What is Financialization? Mimeo, Department of Sociology, UCLA.

Kristjánsson S (1977) Conflict and consensus in Icelandic politics, Ph.D. thesis, University of Iceland.

Langley P (2008) The Everyday Life of Global Finance: Saving and Borrowing in Anglo-America. Oxford: Oxford University Press.

Lapavitsas C (2009) Financialised capitalism: Crisis and financial expropriation, Historical Materialism 17(2), pp. 114-148.

Lehmbruch G (I984) Concertation and the structure of corporatist networks, in Galdthorpe J (ed.) Order and Conflict in Contemporary Capitalism. Oxford: Clarendon Press.

Líndal S (1995) Labour legislation and industrial relationship in Iceland, International Journal of Comparative Labour Law and Industrial Relations 11(2), pp.112-132.

Lipietz A (2001) The fortunes and misfortunes of post-Fordism, in Albritton R, Itoh M, Westra R, Zuege A (eds.) Phases of Capitalist Development. Booms, Crisis and Globalizations. London: Palgrave.

Lucarelli B (2011) The Economics of Financial Turbulence. Alternative Theories of Money and Finance. Cheltenham: Edward Elgar.

Magnússon H (2008) Pension Funds Stand Firm in the Middle of an Economic Upheaval, Icelandic Pension Funds Association, 8 October. Online at <www.ll.is $>$.

Magnússon M (1985) Iceland in transition: Labour and Socio-economic Change before 1940-1985, Ph.D. thesis, University of Lund.

Mellor M (2010) The Future of Money: From Financial Crisis to Public Resource. London: Pluto.

Ministries of Industry and Commerce (1997) Compendium of the Icelandic Financial Market Legislation, Reykjavík. Online at <www.idnadarraduneyti.is $>$.

Ministry of Finance of Iceland (1996) Introduction to the Government Employees Act, No. $70 / 1996$.

Minsky HP (1982) Inflation, Recession and Economic Policy. Brighton: Wheatsheaf Books.

Mjøset L (2000) The Nordic Economies 1945-1980. Oslo: ARENA Working Paper Series, no. 6.

Online at < www.sv.uio.no $>$.

News Frettir (2009a) The Stability Pact in Turmoil, September.

News Frettir (2009b) Lower Taxes for Those with Less Income, October.

Nordic Council of Ministers (2007) Nordic Statistical Yearbook 2007, Statistics Denmark, Copenhagen. Online at <http://statice.is $>$.

NOSOSCO (2010) Social Protection in the Nordic Countries, 2008/2009. Scope, Expenditure and Financing, Copenhagen. Online at <http://nososco-eng.nom-nos.dk>.

OECD (1997) Economic Surveys: Iceland. Paris: OECD Publishing.

OECD (1999) Economic Surveys: Iceland. Paris: OECD Publishing.

OECD (2005) Economic Surveys: Iceland. Paris: OECD Publishing.

OECD (2008) Private Pensions Outlook. Paris: OECD Publishing.

OECD (2009) Economic Surveys: Iceland. Paris: OECD Publishing.

OECD (2011) Economic Surveys: Iceland. Paris: OECD Publishing.

Oh D, Löof H, Heshmati A (2009) The Icelandic Economy: A Victim of the Financial Crisis or Simply Inefficient? Paper no. 199. Stockholm: CESIS. Online at <http://scripts.abe.kth.se>.

Ólafsson S (1981) Modernization in Iceland, Ph.D. thesis, unpublished.

Ólafsson S (1999) The Icelandic model: Social security and welfare in a comparative perspective, in Palier B (ed.) Comparing Social Welfare Systems in Nordic Europe and France, Mire-Drees Collection 4.

Ólafsson S (2001) The Icelandic pension system. Characteristics and prospects, in Palme J (ed.) Privata och offentliga pensionsreformer i Norden. Stockholm: Pensionsforum. 
Ólafsson S (2010) Pensions, Health and Long-Term Care in Iceland, ASISP Network. Online at $<$ http://landinn.is $>$.

Óskarsdóttir S (1997) The use of income policies: The case of Iceland 1969-1994, Ph.D. thesis, University of Iceland.

Polanyi K (1944) The Great Transformation. Boston, MA: Beacon Press.

Polanyi K (1977) The Livelihood of Man. New York: Academic Press.

Portes R, Baldursson MF, Ólafsson F (2007) The Internationalization of Iceland's Financial Sector, Iceland chamber of commerce, Reykjavík. Online at <www.vi.is $>$.

Roerhrbein N (2010) Iceland: Post-eruption controls remain in place, Intelligence on European Pensions and Institutional Investment, 7 October. Online at <www.ipe.com>.

SAL-fréttir (1992).

Schmidt MG (1982) Does corporatism matter? Economic crisis, politics and rates of unemployment in capitalist democracies in the 1970s, in Lehmbruch G, Schmitter PC (eds.) Patterns of Corporatist Policy-Making. London: Sage.

Schmitter P (1989) Corporatism is dead! Long live corporatism, Government and Opposition 24(1), pp. 54-73.

Screpanti E (2001) The Fundamental Institutions of Capitalism. London: Routledge.

Shaikh A (1986) Exploitation, in Eatwell J, Milgate M, Newman P (eds.) The New Palgrave: A Dictionary of Economic Theory and Doctrine. London: Macmillan.

Sighvatsson A (2010) Shedding the Shackles of Capital Controls, Speech of the deputy governor of the Central Bank of Iceland at the breakfast meeting of Icelandic Securities Ltd, Reykjavík, October 07, Bis Review 138/2010. Online at <http://cb.is>.

Sigurjonsson TO (2010) The Icelandic bank collapse: challenges to governance and risk management, Corporate Governance 10(1), pp. 33-45.

Sigurjonsson TO, Mixa MW (2011) Learning from the 'worst behaved': Iceland's financial crisis and the Nordic comparison, Thunderbird International Business Review 53(2), pp. 209-224.

Skýrsla Forseta ASI Um Störf Alpýðusambands Íslands 1956-1998.

Stiglitz J (2001) Monetary and Exchange Rate Policy in Small Open Economies: The Case of Iceland, Central Bank of Iceland, Economic department. Online at <www.sedlabanki.is $>$.

Stockhammer E (2008) Some stylized facts on the finance-dominated accumulation regime, Competition \& Change 12(2), pp. 184-202.

Sveinsson JR (2011) Housing in Iceland in the aftermath of the global financial crisis, in Forrest R, Yip NM (eds.) Housing Markets and the Global Financial Crisis: The Uneven Impact on Households Cheltenham: Edward Elgar.

Tarantelli E (1978) Il ruolo economico del sindacato e il caso italiano. Rome: Laterza.

Toporowski J (2000) The End of Finance. The Theory of Capital Market Inflation, Financial Derivatives and Pension Fund Capitalism. London: Routledge.

Traxler F (1999) The state in industrial relations: a cross-national analysis of developments and socioeconomic effects, European Journal of Political Research 36(1), pp. 55-85.

Trampusch C (2006) Industrial relations and welfare states: the different dynamics of retrenchment in Germany and the Netherlands, Journal of European Social Policy 16(2), pp. 121-133.

Vaiman V, Sigurjonsson TO, Davidsson PA (2011) Weak business culture as an antecedent of economic crisis: the case of Iceland, Journal of Business Ethics 98(2), pp. 259-272.

Valdimarsson OR (2010a) Iceland to Present Bill to Wipe out Personal Debt, Minister Jonasson Says, Bloomberg, 13 October. Online at <www.bloomberg.com>.

Valdimarsson OR (2010b) Iceland Pension Funds to Block \$2 Billion Debt Relief Proposal, Bloomberg, 15 October. Online at <www.bloomberg.com>.

Vasudevan R (2009) The credit crisis: is the international role of the dollar at stake? Monthly Review 60(11), pp. 24-35. 
Wade R, Sigurgeirsdóttir S (2011) Iceland's meltdown: the rise and fall of international banking in the North Atlantic, Real-World Economics Review 56, pp. 58-71.

Zoega G (2002) Inflation and Unemployment in Iceland in the Light of Natural-Rate Theory, Central Bank of Iceland, Economic department. Online at <www.sedlabanki.is $>$.

\section{Author biography}

Francesco Macheda is a Ph.D. candidate in analysis of socioeconomical transformations, and a research assistant in economic sociology at the Università Politecnica delle Marche. 